\title{
The impact of EU intervention on political parties' politicisation of Europe following the financial crisis
}

This paper examines the effect of financial crisis and economic intervention by the European Union on political parties' politicisation of the EU within national elections. Data from the Manifesto Project for elections between 2002 and 2017 in twelve Eurozone countries is used to assess how the crisis and intervention altered the saliency, position and clarity of parties' EU policies. The analysis shows that the crisis only led to an increase in EU saliency in those states not subjected to intervention whilst intervention is actually associated with a decrease in the saliency of the EU. In terms of increasing euroscepticism, intervention appears to exhibit a greater effect than the crisis although the results display marked asymmetry between different parties on the left and right. The same is observed to be the case for the level of blurring that parties are engaged in to mask their EU positions. The implications of the findings suggest that economic intervention within the EU has negatively impacted democracy in intervened member states by reducing the manoeuvrability of parties to provide voters with clear choices on the direction of European integration.

Keywords: European integration, politicisation, intervention, political parties, responsiveness

\section{[Accepted Manuscript version] \\ Turnbull-Dugarte, Stuart J.}

This paper assesses the effect of the global financial crisis and economic intervention by the European Union (EU) on political parties' politicisation of the EU within national elections. The absence of politicisation over the EU at both the domestic and European Parliament (EP) level has been noted extensively by scholars of EU politics (Reif and Schmitt 1980; Scharpf 1999; Schmidt 2013), with the lack of politicisation often cited as the root cause behind the polity's democratic deficit (Follesdal and Hix 2006). EU politicisation is considered normatively good in that when political actors allow for the competition of issues regarding the structure and output of the polity, electorates from EU states are provided with the means of expressing their political preferences regarding the same (Hix 2008). Whilst pro-europeans might be weary of rising politicisation as it has often been associated with euroscepticism (Statham and Trenz 2015), EU politicisation also facilitates the expression of political alternatives with 
representative potential and is therefore important for guaranteeing electoral representation. Given the importance of politicisation for ensuring the polity is afforded the necessary input legitimacy to remedy its perceived democratic impotencies (Hix 2008; Schmidt 2006), gaining an understanding of what drives and restrains EU politicisation amongst parties is important.

EU politicisation has been conceptualised by De Wilde \& Zürn (2012; see also, De Wilde, Leupold and Schmidtke 2016; Statham and Trenz 2013) as consisting of three components: i) increasing saliency of the EU, ii) polarisation of views in relation to the EU, and iii) a widening of the number of actors engaging in political interest with the EU. Since the purpose of this study is to assess changes in EU politicisation for a particular set of actors, individual political parties, the focus of this analysis is on the first two components assessing the saliency of the EU and the positional stance of parties in relation to Europe as well as the clarity of their position within national elections, therefore providing from public choice (Zürn 2019).

A vast literature highlights that the political consequences of the economic crisis have been far from nugatory. The majority of the literature, however, has tended to focus on the changes in the demand-side of political representation. The crisis has been shown to have led to the ousting of incumbent governments en masse across the EU (Bosco and Verney 2012), increased levels of euroscepticism amongst European populations (Börzel 2016; De Vries 2018; Hobolt and De Vries 2016), the emergence of eurosceptic and populist parties (Hobolt and Tilley 2016; Hooghe and Marks 2018) as well as the restructuring (Hernandez \& Kriesi 2016) and polarisation (Charalambous et al. 2018) of party systems and political space (Hutter et al. 2018; Katsanidou and Otjes 
2016). Research assessing the impact of economic intervention has also revealed its negative effects on both satisfaction with democracy (Ruíz-Rufino and Alonso 2017) as well as electoral support for mainstream, particularly left-leaning, parties (Alonso and Ruíz-Rufino 2018).

There has also been a notable effort to analyse the impact of the financial crisis on EU politicisation, with the majority of work focusing on EU saliency within the public sphere (Höglicher 2016; Hutter, Grande and Kriesi 2016; Leupold 2016). The evidence provided by these initial studies suggests that the crisis had an incremental effect on EU politicisation. However, given the approach of these studies has been to focus on the politicisation of the EU within the public discourse of partisan competitions (Hutter and Kriesi 2019) -they rely on the coding of printed press- shifts in how much the media is talking about the EU might not reflect the same observed by parties given that domestic public debate is another display of the demand-side. Moreover, relying on material from the printed press is not without its methodological limitations, in particular are the clear concerns regarding the motives of the press to i) focus on issues that represent conflict, and ii) rely on sources close to their own networks and arbitrary selection processes, resulting in bias (Van Aelst, et al. 201; Van Dalen 2012).

This study focuses on the supply-side of electoral representation and assesses politicisation of the EU as communicated by parties. Given that parties are the means via which opposing policy alternatives are offered to electorates to choose from, it is important to understand when and how individual parties politicise and depoliticise issues that gain greater salience amongst the electorate. 
An additional lacuna in the crisis-focused literature, is how the decisions of certain states to submit themselves to economic constraints and increased levels of EU control have affected parties' willingness to compete over Europe. Nor is it clear whether the impact of economic intervention or crisis displays a homogenous effect across parties from different ideological backgrounds. Empirically, this paper assesses the effect of economic intervention in the context of the financial crisis on individual parties' programmes. The evidence shows that the financial crisis, on average, marginally increased EU saliency but that this effect was only observed in those member states not subjected to intervention. Economic intervention on the other hand is associated with a substantive decrease in EU saliency. Moreover, parties adjust their positions and their positional clarity asymmetrically to both the crisis and EU intervention. The empirical analysis relies on data provided by the Manifesto Project (MARPOR) across elections taking place in twelve members of the Economic and Monetary Union (EMU), those that constitute that of the Stage III of the EMU ${ }^{\mathrm{i}}$, and includes a total of 339 party manifestos over fifty elections.

\section{Theoretical Framework}

To understand the motivations behind partisan responses to the financial crisis and EU intervention, I adopt the assumption that most parties operate as vote-maximisers who alter and reshape their policy platforms to become closer to the median voter in order to reap the electoral benefits doing so provides (Downs 1957; Strøm 1990). This understanding of political parties views their behaviour to be governed by principles of responsiveness; that is parties promote policy positions and increase their importance in electoral campaigns in response to policy demands and issue conflicts salient amongst the electorate at the time. 
This interpretation of responsiveness has largely been applied to explain the lack of EU-centric policy competition at both the national and supranational level (De Vries 2007; Green-Pederson 2012; Kriesi 2007; Külahci 2012; Ladrech 2002; Mair 2000; Penning 2006; Reif and Schmitt 1980). Parties in Europe have historically elected not to politicise the EU as it has not wielded any notable level of importance for national voters and as a result, parties do not observe any electoral incentives to compete over a political issue that will not provide them with an increased vote revenue vis-à-vis their competitors.

De Wilde and Zürn (2012) argue that voters and their electoral preferences are the catalytic drivers of EU politicisation. In brief, the authors maintain that EU politicisation is driven in tandem by the transferring of political sovereignty to the EU with different steps of integration representing 'critical junctures' (Almeida 2012; Grande and Hutter 2016; Hooghe and Marks 2009; Hutter et al. 2016) that voters are no longer willing to permissively accept. This occurs alongside increasing perceptions amongst voters that the EU "matters" (Hooghe and Marks 2009, 2018; Spoon and Williams 2017; Statham and Trenz 2013, 2015; Taggart 1998). As the polity's competences have expanded over a wider range of policy areas, particularly relating to monetary and fiscal policy in EMU states, European electorates have become more aware of the political role the EU plays on influencing policies that have an effect on their daily lives and care more about the polity as a result (Statham and Trenz 2012, 2015). Political entrepreneurs, often parties emerging on the polar ends of the ideological spectrum, then monopolise and own the EU concerns of voters that have hitherto not been catered to by mainstream parties (Hooghe and Marks 2018). These 
new parties are then able to alter the party system as the electoral threat they suppose for pro-integrationist parties can influence the EU positions of their competitors (Meijers 2017; Spoon and Williams 2017).

Whilst one might note that the direction of mass-party linkages can also operate in the reverse causal order (i.e. parties shape voters' views and not voters' shaping parties' positions), the ability of parties' to shape voters' EU positions is of questionable efficacy (Adams, Ezrow and Somer-Topcu 2011, 2014; De Wilde and Zürn 2012) whilst the ability of voters to shape parties' positions on the EU appears notably stronger (Carubba 2001; Schmitt and Thomassen 2000; Steenbergen, Edwards and De Vries 2007).

The existing literature that focuses on the political consequences of the financial crisis would suggest that we might expect a change in the partisan politicisation of Europe. This is due to a substantial change in the demand-side of the representative equation with the crisis engendering a substantial shift in the saliency and level of euroscepticism among European voters (Hobolt and De Vries 2016; Hobolt and Tilley 2016; Hooghe and Marks 2018; Hutter and Grande 2014; Hutter, Grande and Kriesi 2016), an increased understanding of the EU and its role of its institutions (Ruíz-Rufino and Alonso 2017), as well as a rise in the politicisation of the EU within the public sphere and domestic debate (Höglicher 2016; Hutter, Grande and Kriesi 2016; Leupold 2016). Paramount, also, is the link between voters and the role of the EU in the management/responsibility of the crisis as well as its advocacy for the unpopular austerity agenda promoted across the continent (Magone 2016). 
Additionally, the initial work assessing the impact of the crisis on the supplyside, specifically experts' perceptions on parties' EU policies, shows that the crisis did, if however in a small manner, impact parties' EU policy positions with parties on the extreme end of the ideological spectrum being more responsive to the growing euroscepticism engendered by the crisis (Rohrschneider and Whitefield 2016). The same is observed to occur amongst parties in the EP elections (Braun et al. 2019). The financial crisis is therefore identified as a critical juncture in terms of both citizens' knowledge of the EU, the perceived importance it has over their daily lives, as well as their views towards the polity. Adopting as valid the Downsian assumption of the responsiveness of parties to shifts in electoral preferences, parties should be expected to change the politicisation of the EU in response to the electoral shifts caused by the financial crisis.

Of course, it might be the case that parties are unresponsive to electoral preferences, in which case we might observe attempts by parties to actively decrease the politicisation of the EU in order for them to continue approving policy outcomes at the supranational level that are to their liking but would not sell well electorally at the domestic level (Mair 2009, 2013). That being said, because governments can, and have (Hobolt and Tilley 2014), use the EU as a scapegoat to blame for unpopular policies, they may also wish to take advantage of the opportunity the crisis affords them to expand upon this blame-shifting strategy in a system of multi-level governance. It is therefore likely that parties will seek to increase the politicisation of the EU in response to the financial crisis as the issue has become domestically important on the demandside and politicising the EU in response allows them to both be responsive to voter preferences and to shift the focus towards the EU and away from their own domestic 
policies. H1: In response to the financial crisis, individual parties will increase: i) how much they discuss the EU (saliency thesis); ii) the europscepticism of their EU policy positions (euroscepticism thesis), and iii) the clarity of their EU policies (blurring thesis).

The events of the global financial crisis, how it engendered the European debt crisis and the need of European governments to respond to them have been detailed elsewhere (Blyth 2013; Copelovitch, et al. 2016; Hall 2014). Relevant to the present argument, is that domestic governments were forced to provide liquidity for the private banks in their countries, effectively moving the unsustainable levels of debt from the balance sheets of banks onto that of the public purse. The results of these dives into Keynesianism left a collection of states which, as the severity of the economic crisis crippled their own domestic revenue sources and in the context of dried up international capital, were left in the precarious situation of being unable to fulfil their own financial obligations. The result of this situation being the financial intervention of the EU in six of these states in exchange for their submission to the economic constraints and reform demands solicited from them by the respective Memorandum of Understanding (MoU) they agreed to ${ }^{\mathrm{ii}}$.

Here, I argue that upon submitting themselves to the additional constraints of the MoU that demanded substantial reforms of the signatories' domestic economies as well as the straitjacket that would strangle any room for manoeuvre with regards fiscal policy, member states were engaging in an additional transfer of sovereignty tantamount to treaty change. That is, the EMU members that were economically intervened were advancing into a new, deeper stage of European integration that had not yet been 
experienced by the other EMU members. As such, this meant that EMU states were now operating within a two-tier system of constraints (Alonso 2014; Alonso and RuízRufino 2018) that limited parties' ability to fulfil their supply-side role for the electorate, with non-intervened states operating under regular EMU rules (de jure constraints) and MoU signatories operating under rules that prohibit any room for fiscal flexibility (de facto constraints).

Since there is asymmetry in the level of EU constraints between states, there is likely to be asymmetry in the responses of individual parties from different states. Parties in intervened states have lost the ability to respond to their electorates in terms of economic policies that diverge from the deficit- and debt-reduction objectives of the EU. Of substantial importance to the argument made here is that the effect of the same has been to see party competition over economic policy and the EU converge (Katsanidou and Otjes 2016) where competition over austerity in intervened states is conflated with views on EU integration. As Mair (2013) highlighted, the problem with curtailing the ability of citizens to challenge the policy direction of a polity, is that electoral frustration inevitably turns towards the polity itself. When member states have their hands tied by supranational externalities, electorates will seek to express their discontent towards the externality and demand their representatives respond. Should parties indeed react responsively to increased levels of economic constraint, one would expect the politicisation of the EU to increase in those states. Given that steps towards greater integration tend to increase EU politicisation (De Wilde and Zürn 2012; Grande and Hutter 2016) and MoUs represent such a step (Alonso and Ruíz-Rufino 2018), politicisation will likely rise. Hence, $\boldsymbol{H} 2 \boldsymbol{a}$ (authority transfer thesis): Parties in member 
states subjected to economic intervention will increase: i) how much they discuss the EU ii) the euroscepticism of their position), and iii) the clarity of their EU policies.

There is, however, an argument to suggest that intervention may decrease the politicisation of the EU. Traber et al. (2018), for example, find that in policy areas where the political room for manoeuvre is low, parties tend to repress the saliency of these issues. The authors show this empirically by demonstrating that even in the context of high public saliency for economic issues, when these issues are unyielding to international constraints, parties remain silent on them. There is, therefore, conflicting theoretical and empirical expectations regarding the direction of the impact of intervention and parties may be more likely to respond to a loss of manoeuvrability by supressing the issue and by blurring their position. Indeed, efforts by state governments to isolate crisis-responses at the EU level within an intergovernmental framework outside of the community apparatus (therefore avoiding referendums required by treaty reforms) suggest that parties who have their hands tie do wish to suppress the opportunities for contestation and political choice. Hence, H2b (manoeuvrability thesis): Parties in member states subjected to economic intervention will decrease: i) how much they politicise the EU, and ii) the clarity of their EU policies.

Finally, parties have engaged with the process of European integration for different motives (De Vries and Hobolt 2012; Hellström and Blomgren 2016; Hooghe et al. 2002; Whitefield and Rohrschneider 2019), that often reflect their ideological orientations. Since parties' motivations of support for the EU as well as their overall view of the EU policy agenda are heterogeneous, increased levels of EU intervention in 
support of fiscal austerity are likely to lead to heterogeneous responses from individual parties in those states.

For example, parties on the left view the EU as a means of enshrining social welfare provisions at the supranational level (Hobolt 2015; Hooghe, et al. 2002) and will likely be vocally critical of any attempts to undermine welfare spending (e.g. austerity measures). Amongst the left, social democratic parties may prove less responsive to changing electoral preferences and saliency on the EU than parties on the far-left. This is because social democratic parties have often formed part of governing coalitions that have participated in numerous integrationist steps in the design and expansion of the EU. They are, therefore, somewhat tied by their pro-integrationist association with the polity and cannot abandon or suppress this without running the risk of damaging the integrationist party brand (Whitefield and Rohrschneider 2019).

That being said, whilst we might not expect them to alter their EU position (i.e. their level of euroscepticism/europhilia) there is a strong incentive for them to alter the level of EU saliency and their positional clarity. Pro-integrationist social democrats may actively seek to increase the saliency of their pro-EU status to distance themselves spatially from Eurosceptic challengers as a strong pro-EU alternative. Or, as observed in some instances amongst pro-EU parties (Adam et al. 2017; Rovny 2012), they may reduce further the saliency of Europe and purposefully blur their position and increase the ambiguity of their position in order to appeal to a wider voter pool who fall on either side of the EU debate. 
Conversely, parties on the right are less critical of the EU's response mechanisms supporting contractionary fiscal policies or the imposing of the same in MoU signatory states because these are in line with their own ideological worldview. There is therefore, less of an incentive for the right to increase the saliency of the EU and, in fact, they may seek to reduce it in order to supress contestation of goals in line with their own policy objectives. Additionally, since Alonso and Ruiz-Rufino (2018) find that parties suffer distinct electoral losses as a result of intervention, with mainstream parties on the left suffering defeats to a far greater extent than those on the right, this will also likely shape the way they respond. Given parties support the EU for asymmetric reasons and are castigated by the electorate for the role of EU constraints in varying degrees, their treatment of the EU following intervention is likely also asymmetrical. Therefore, H3: Parties from different ideological families will react asymmetrically to the crisis and economic intervention.

\section{Data}

The analysis that follows relies on data from elections in twelve Eurozone member states between 2002 and 2017. Since one of the primary explanatory variables is economic intervention, which represents a change in the level of europeanisation over states' domestic economic policies, limiting the population of the study to only those member states that were subject to the same EU-level constraints allows for a better isolation of the causal impact of intervention. Hence only Eurozone member states are included as the inclusion of non-EMU states would lead to variation in the level of europeanisation prior to treatment (i.e., changes in the level of EU constraints). The selection of countries using this rationale is in line with other work assessing the causal impact of EU intervention on domestic outcomes (Ruíz-Rufino and Alonso 2017; Alonso and Ruíz-Rufino 2018). Observations in the data represent individual parties in 
a given election year $(\mathrm{N}=339)$ and the data is structured so that each party represents a panel $(\mathrm{N}=114)$ with elections representing the time units. All parties are included in the main analysis.

Data for the dependent variables relies on coded manifesto data using the MARPOR dataset. The selection of manifestos as the main source is commonplace within the party literature and remains the most appropriate data source for assessing party position trends given that it provides a real-time indicator of a party's position within a specific election. Moreover, manifestos have elevated thresholds (Dolezal et al. 2012) where different policy issues compete for space within a limited document. Issues that make the cut are then those considered to be superior to other less-important concerns (Eder, Jenny and Müller 2017) and are thus those that a party feels are i) most important to their core values and/or ii) most likely to provide them with positive electoral returns. Alternatives to using manifesto data, such as relying on expert surveys (Polk et al. 2017), are less appropriate for the research question at hand given that they do not provide a real-time assessment of changes in party policies between elections. The other alternative, media reporting (Leupold 2016), whilst a powerful data source for country-level analysis is less useful for assessing changes within parties or on the supply-side of democratic representation.

There are the three dependent variables (detailed operationalisation in appendix) that taken together serve as an efficient means of measuring how the financial crisis and EU intervention engendered an EU-issue orientation in party programmes. The first measures EU saliency, which is defined as the relative importance parties give to the issue within their manifesto (Lowe et al. 2011: 133-134). The second dependent 
variable measures the overall party EU policy (EU position) with higher values indicating that a party is more europhile and lower values indicating euroscepticism.

The third dependent variable measures the clarity of party's EU positions. A tool that mainstream parties have adopted when under pressure to take a position where there is a lack of electoral distinction or when there is internal party dissent, is to present an ambiguous policy stance in order to cater to a wider spectrum of potential voters and to muffle internal discontent (Adam et al. 2017; Rovny 2012). Two avenues are available to parties to achieve this; they can either stay silent on the issue or blur their position. The clarity of a party's EU position is indicated from 0 (completely ambiguous) to 1 (completely unambiguous) and measures the consistency of a party's position on Europe based on the difference in their pro- and anti-EU stances in relation to the total space they dedicate to the EU within the manifesto ${ }^{\mathrm{iii}}$. In order to ensure that the indicator is capturing parties that are (de)blurring, as opposed to those who remain silent, clarity is only computed for parties who discuss Europe.

There are two core explanatory variables. Firstly, intervention is a dichotomous variable that indicates the beginning of economic intervention between 2010 and 2011 in those member states that were subject to monitoring by the EU. Secondly, to capture the effect of the financial crisis, I replicate the economic misery indicator used in the work of Hernandez and Kriesi (2016) as well as others (Kriesi and Pappas 2015; Otjes and Kastsanidou 2017). Misery is computed from an exploratory factor analysis (see appendix Table A3) of changes between time $t$ (election year) and the year prior in: gross domestic product (GDP), unemployment rate, and government debt. ${ }^{\text {iv }}$ These macroeconomic measures load onto a single dimension with the misery variable serving 
as a general index of the combined factor scores: higher values indicate a greater level of economic misery. As argued by Hernandez and Kriesi (2016), the use of an indicator capturing overall economic misery makes sense both conceptually and empirically since the electorate is not likely to have an in-depth understanding of specific macroeconomic indicators but will likely be aware of the overall state of the economy.

At the individual party level, I control for incumbency ${ }^{v}$ at time $t$. Forming part of a governing party can exhibit a moderating effect on a party's overall position to the EU (Gifford 2014; Spoon and Williams 2017; Taggart 1998). Since governing status tends to tranquilise party's EU positions, it is likely to also influence EU saliency and positional clarity as well. Secondly, party size is included and is measured as the vote share enjoyed by the party at time $t-1$. Policy-seeking parties are less likely to feel the pull of exogenous shocks since they cater their policy offerings to their select group of core voters (Strøm 1990). Since office-seeking parties are normally larger parties, incorporating the electoral size of a party should capture the varying responsiveness of parties based on their diverging electoral objectives.

At the country (party system) level, the effective number of electoral parties $(E N E P)$ is included. Political systems that adopt a more proportional system of representation tend to have a greater number of parties which represent a wider spectrum of political views meaning that, in theory, there is a greater level of political representation. In counties where there are a larger number of parties, or in systems where new and electorally competitive parties are emerging, one may find that the issue of the EU is given more prominence. Moreover, since new challenger parties have been found to impact the politicisation of the EU this will be catered for in the ENEP 
variable: should electorally competitive parties emerge this will be captured by an increase in the ENEP.

The presence of eurosceptic parties has been found to shape existing parties' view on the EU (De Vries 2007; Meijers 2017; Spoon and Williams 2017). In order to control for the potential impact of the same on EU politicisation, an indicator is incorporated into the model that captures the domestic level of EU-issue policy positions at time $t-1$ (europhilia). This is indicated by taking the mean EU position of parties within each country weighted by each party's vote share, with higher values signalling greater level of domestic partisan support for the EU. Capturing the eurosceptic tendencies at the system level, as opposed to identifying the presence of individual parties, is more efficient as it is based purely on positions cited in manifestos and does not depend on conceptualisations of eurosceptic parties.

In order to test $\mathrm{H} 3$, the models presented in the analysis are estimated using different subsamples for each party type. Running estimations using subsamples has the benefit of allowing the variable that identifies the subsample to be interacted with all of the other variables in the model, which is advantageous in terms of interpreting the ceteris paribus assumption of the variables. I create three party family categories ${ }^{\mathrm{vi}}$ by collapsing some of the categories used in the MARPOR dataset, reducing them into three: Far-Left (1), Social Democrat (2), and Centre-right (3). Parties are coded as: FarLeft if they are identified as either Green or Communist; Social Democrat, if they are identified as such. Christian Democrat and Conservative parties are coded as Centreright. The collapsing of parties in this way replicates groupings carried out in similar work (Haupt 2010). Where the grouping is distinct in this analysis, however, is that I disaggregate social democrats from other left-leaning parties since EU-centric attitudes 
of these parties are likely distinct (Whitefield and Rohrschneider 2019) and differentiating between them facilitates the testing of the third hypothesis.

Since the main objective of the paper is to isolate the impact of crisis and EU intervention on the programmatic change within individual political parties and observations represent manifestos from parties across elections, I follow the Beck and Katz (1995) approach applying panel-corrected standard errors, and include lagged values of the dependent variable alongside party and year fixed-effects ${ }^{\text {vii }}$. Summary statistics are presented in the appendix.

\section{Analysis}

An initial visualisation provides an intuitive idea of how both the crisis and intervention play a role in shaping the levels of party politicisation of the EU. Figure 1 visualises the trends in the level of saliency of the EU for parties across both economically constrained and non-constrained member states. In the years between 2002 and 2011, parties from intervened and non-intervened states display different levels of EU saliency whilst following a clearly visualised parallel trend. With the arrival of the financial crisis and the consequential eurozone crisis the parallel trend is ruptured: nonintervened states show a marked increase in EU saliency whilst intervened states show a marked decrease in the same. The means of empirically assessing this divergence is the subject of the following sections. 


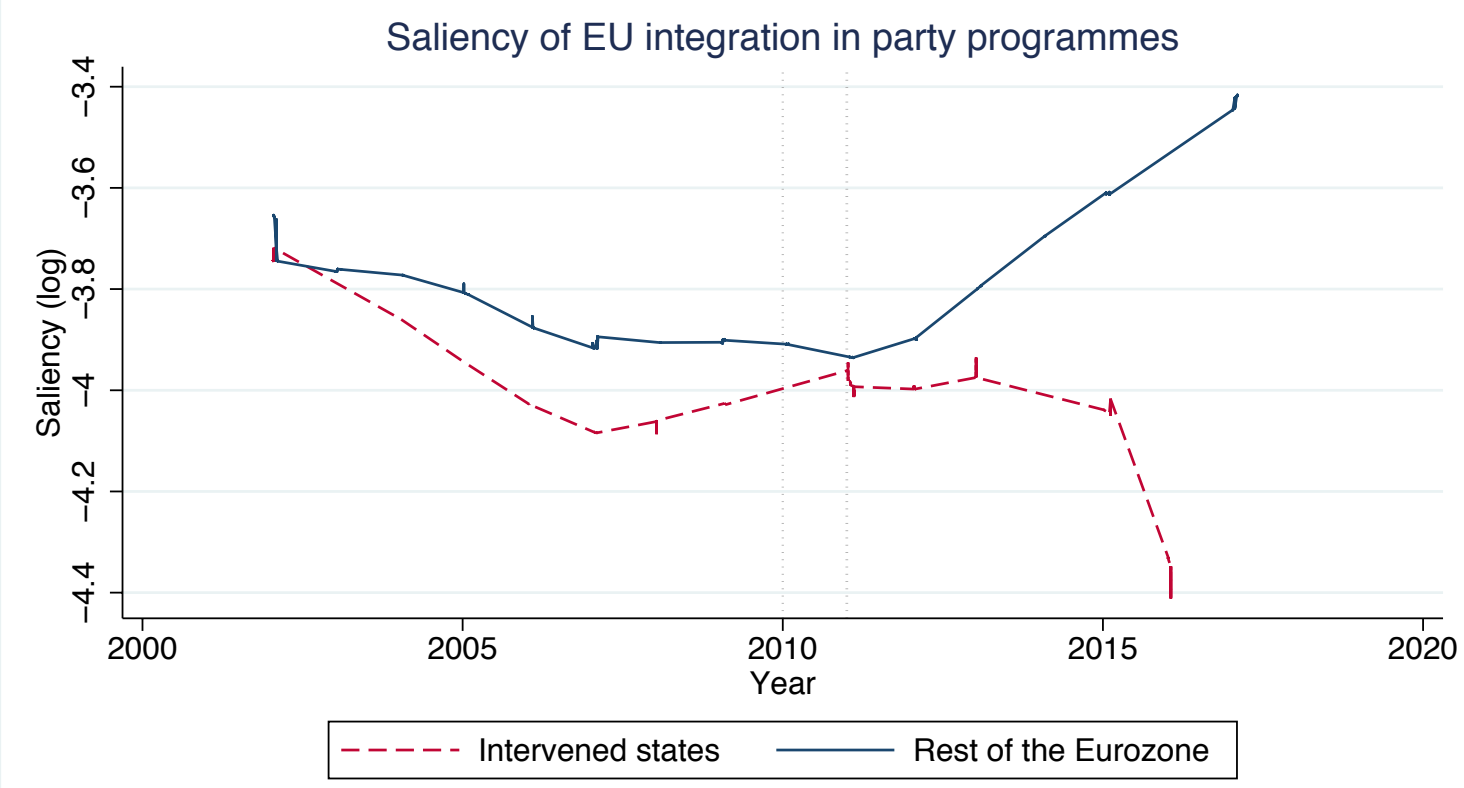

Intervened states: GR, IE \& PT (2010); ES \& IT (2011)

Dotted vertical lines: application of interventions

Figure 1: EU saliency amongst intervened and non-intervened states (2002-2017)

First, I test the impact of crisis and intervention on EU saliency (Table 1). The average value of the dependent variable in the sample has been incorporated each table to facilitate an understanding of the substantive magnitude of the coefficients. Overall, in terms of explaining the extent which parties alter the amount of space they dedicate to EU-issues, there is strong support for both $\mathrm{H} 1$ and $\mathrm{H} 2 \mathrm{~b}$ : the crisis is associated with an increase in the levels of EU saliency whilst economic intervention depresses it.

Table 1: Crisis, intervention and EU saliency

(Model 1) (Model 2) (Model 3) (Model 4) (Model 5)

$\begin{array}{lccccc}\text { Misery } & 0.06^{* * *} & 0.05^{* *} & 0.10^{* * *} & 0.09 * * * & 0.09 * * * \\ & (0.02) & (0.02) & (0.02) & (0.02) & (0.03) \\ \text { Intervention } & -0.50^{* *} & -0.66^{* *} & -0.03 & -0.06 & \\ & (0.25) & (0.26) & (0.33) & (0.34) & \\ \text { Intervention*Misery } & & & -0.07 * * & -0.09 * * * & \\ & & & (0.03) & (0.03) & \\ \text { Incumbency } & & 0.23 * & & 0.20 & 0.18 \\ & & (0.13) & & (0.13) & (0.14) \\ \text { Party size } & & -0.01 & & -0.01 & 0.02 * *\end{array}$


Party type

$(0.01) \quad(0.01) \quad(0.01)$

(base: Christian dem)

\begin{tabular}{|c|c|c|c|c|c|}
\hline Green & & $\begin{array}{c}-0.89 * \\
(0.54)\end{array}$ & & $\begin{array}{l}-0.96^{*} \\
(0.51)\end{array}$ & $\begin{array}{c}-1.75 * * * \\
(0.66)\end{array}$ \\
\hline Communists & & $\begin{array}{l}-0.15 \\
(0.47)\end{array}$ & & $\begin{array}{l}-0.15 \\
(0.45)\end{array}$ & $\begin{array}{l}-0.43 \\
(0.43)\end{array}$ \\
\hline Social democrats & & $\begin{array}{l}-0.19 \\
(0.36)\end{array}$ & & $\begin{array}{l}-0.19 \\
(0.36)\end{array}$ & $\begin{array}{l}-0.59 * \\
(0.31)\end{array}$ \\
\hline Liberals & & $\begin{array}{l}-0.16 \\
(0.42)\end{array}$ & & $\begin{array}{l}-0.21 \\
(0.40)\end{array}$ & $\begin{array}{c}1.83 * * * \\
(0.36)\end{array}$ \\
\hline Conservatives & & $\begin{array}{l}-0.22 \\
(0.30)\end{array}$ & & $\begin{array}{l}-0.20 \\
(0.28)\end{array}$ & $\begin{array}{l}-0.26 \\
(0.29)\end{array}$ \\
\hline Nationalists & & $\begin{array}{l}-0.69 \\
(0.44)\end{array}$ & & $\begin{array}{l}-0.69 \\
(0.42)\end{array}$ & $\begin{array}{c}-1.22 * * * \\
(0.39)\end{array}$ \\
\hline Agrarians & & $\begin{array}{c}0.60 \\
(0.54)\end{array}$ & & $\begin{array}{c}0.52 \\
(0.52)\end{array}$ & $\begin{array}{c}0.15 \\
(0.64)\end{array}$ \\
\hline Ethnic/Regional & & $\begin{array}{c}-1.10^{* *} \\
(0.44)\end{array}$ & & $\begin{array}{c}-1.08 * * \\
(0.43)\end{array}$ & $\begin{array}{l}-0.97 \\
(0.75)\end{array}$ \\
\hline Niche-issue & & $\begin{array}{l}-0.52 \\
(0.49)\end{array}$ & & $\begin{array}{l}-0.52 \\
(0.46)\end{array}$ & $\begin{array}{c}-3.89 * * * \\
(0.82)\end{array}$ \\
\hline DV (lag $t-1)$ & $\begin{array}{c}-0.20 * * * \\
(0.07)\end{array}$ & $\begin{array}{c}-0.23 * * * \\
(0.07)\end{array}$ & $\begin{array}{c}-0.18 * * * \\
(0.07)\end{array}$ & $\begin{array}{c}-0.22 * * * \\
(0.07)\end{array}$ & $\begin{array}{c}-0.38^{* * *} \\
(0.09)\end{array}$ \\
\hline Europhilia & & $\begin{array}{c}-0.01 * * * \\
(0.00)\end{array}$ & & $\begin{array}{c}-0.01 * * * \\
(0.00)\end{array}$ & $\begin{array}{c}-0.02 * * * \\
(0.00)\end{array}$ \\
\hline ENEP & & $\begin{array}{c}0.09 \\
(0.08)\end{array}$ & & $\begin{array}{l}0.13^{*} \\
(0.08)\end{array}$ & $\begin{array}{c}0.15 \\
(0.12)\end{array}$ \\
\hline Party FE & Yes & Yes & Yes & Yes & Yes \\
\hline Year dummies & Yes & Yes & Yes & Yes & Yes \\
\hline Mean DV value & -3.81 & -3.81 & -3.81 & -3.81 & 3.71 \\
\hline Constant & $\begin{array}{c}-4.80 * * * \\
(0.43)\end{array}$ & $\begin{array}{c}-4.48 * * * \\
(0.57)\end{array}$ & $\begin{array}{c}-4.70 * * * \\
(0.43)\end{array}$ & $\begin{array}{c}-4.55 * * * \\
(0.55)\end{array}$ & $\begin{array}{c}-4.94 * * * \\
(0.68)\end{array}$ \\
\hline Observations & 339 & 339 & 339 & 339 & 194 \\
\hline R-squared & 0.68 & 0.71 & 0.69 & 0.72 & 0.75 \\
\hline N parties & 114 & 114 & 114 & 114 & 62 \\
\hline
\end{tabular}

Panel-corrected standard errors(two-tailed) in parentheses $* * * \mathrm{p}<0.01, * * \mathrm{p}<0.05, * \mathrm{p}<0.1$

In Models 1 and 2 show the effect of misery and intervention on EU saliency with and without controls respectively. As visualised in Figure 1, we observe a significant increase in EU saliency associated with economic hardship, but the reverse is true for economic intervention. Parties in states subjected to monitoring from EU institutions reduce, on average, how much they are willing talk about the EU. The significantly 
negative intervention coefficient is also substantively larger in comparison to the positive effect of misery.

In Models 3 and 4, the interaction between misery and intervention status is estimated. The positive coefficient of misery and the negative coefficient of the interaction term show that the increase in EU saliency is conditional on intervention status. For ease of interpretation, the average marginal effect (AME) of misery conditional on intervention is visualised in Figure 2: misery only exercises a positive effect statistically distinct from zero for those states that have not been intervened by the European institutions. Model 5 estimates the effect of misery on a subset of states that were not intervened: the positive association of misery remains constant. Framing this is the context of party responsiveness, it is clear that only parties in non-intervened states display increases in EU saliency as their countries suffer economic crisis whilst parties in intervened states observe, on average, a significant reduction in EU saliency.

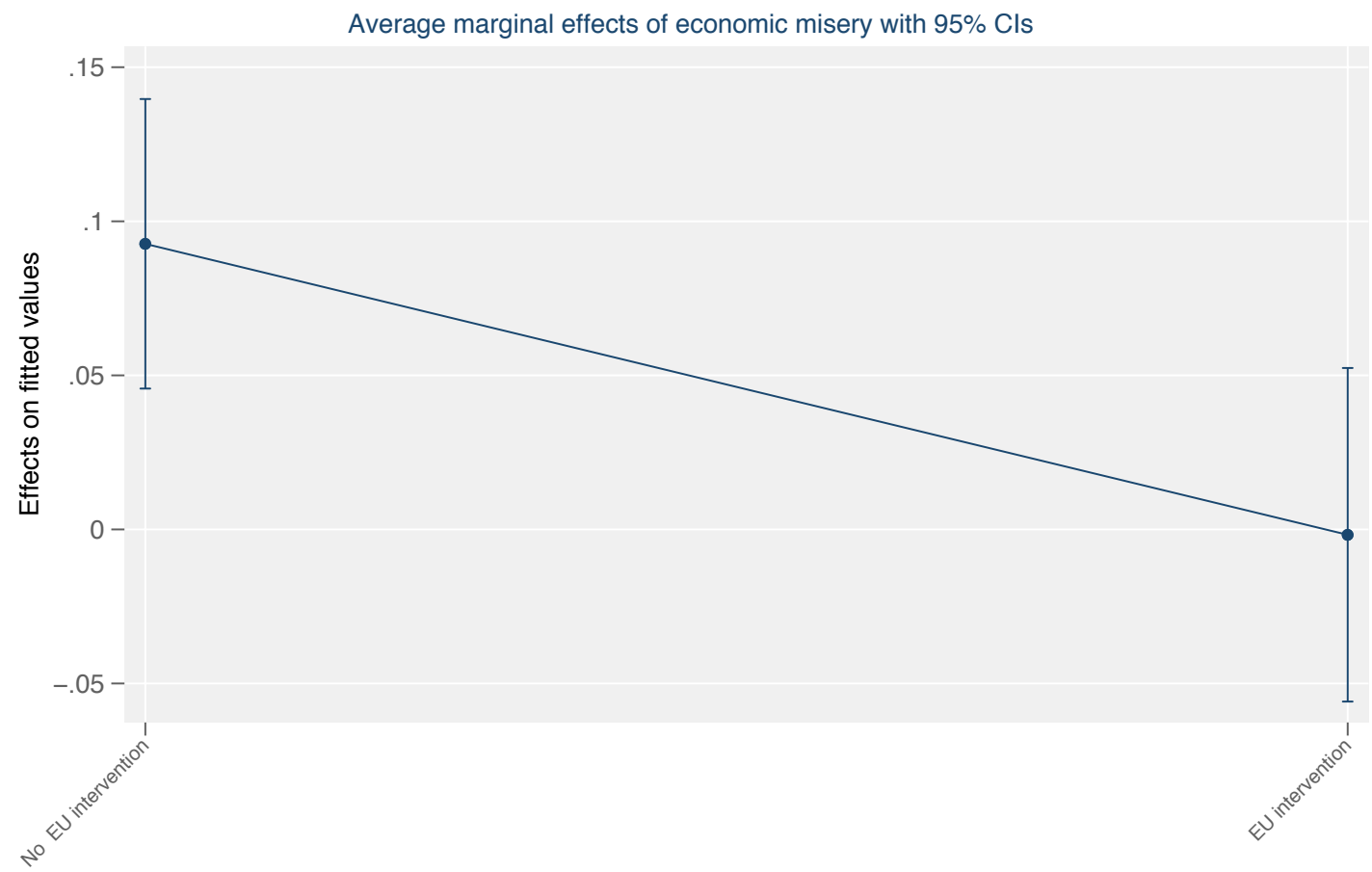

Figure 2: AME of interaction 
Table 2 displays the estimates on parties' EU policy and the positional clarity. Model 6 tests the effect of misery and intervention conditional on the full vector of controls. Parties in intervened states appear to become significantly more eurosceptic. Misery, on the other hand appears to reduce (increase) parties' euroscepticism (europhilia) although, as in the case of saliency, the effect is smaller than intervention. The result of the interaction (Model 7) confirms that parties in intervened and non-intervened states act in significantly different ways to the crisis (see Figure A1 for AME). Model 8 estimates the effect of misery on only those non-intervened states with the coefficient representing a substantively strong effect on parties' EU positions.

Table 2: EU position \& positional clarity

\begin{tabular}{|c|c|c|c|c|c|c|}
\hline & (6) & $\begin{array}{l}\text { Position } \\
(7)\end{array}$ & $(8)$ & (9) & $\begin{array}{l}\text { Clarity } \\
(10)\end{array}$ & $(11)$ \\
\hline Misery & $\begin{array}{c}0.18 * * * \\
(0.04)\end{array}$ & $\begin{array}{c}0.33 * * * \\
(0.05)\end{array}$ & $\begin{array}{c}0.39 * * * \\
(0.06)\end{array}$ & $\begin{array}{c}0.02 * * * \\
(0.01)\end{array}$ & $\begin{array}{c}0.03 * * * \\
(0.01)\end{array}$ & $\begin{array}{c}0.04 * * * \\
(0.01)\end{array}$ \\
\hline Intervention & $\begin{array}{c}-1.12^{* *} \\
(0.49)\end{array}$ & $\begin{array}{l}1.06^{*} \\
(0.58)\end{array}$ & & $\begin{array}{l}-0.04 \\
(0.08)\end{array}$ & $\begin{array}{c}0.09 \\
(0.11)\end{array}$ & \\
\hline Intervention*Misery & & $\begin{array}{c}- \\
0.35 * * * \\
(0.07)\end{array}$ & & & $\begin{array}{l}-0.02 * \\
(0.01)\end{array}$ & \\
\hline Incumbency & $\begin{array}{c}0.07 \\
(0.29)\end{array}$ & $\begin{array}{l}-0.05 \\
(0.27)\end{array}$ & $\begin{array}{l}-0.06 \\
(0.31)\end{array}$ & $\begin{array}{l}-0.03 \\
(0.05)\end{array}$ & $\begin{array}{l}-0.04 \\
(0.05)\end{array}$ & $\begin{array}{l}-0.05 \\
(0.08)\end{array}$ \\
\hline Party size & $\begin{array}{c}0.02 \\
(0.02)\end{array}$ & $\begin{array}{c}0.02 \\
(0.02)\end{array}$ & $\begin{array}{c}0.07 * * \\
(0.03)\end{array}$ & $\begin{array}{l}0.01^{* *} \\
(0.00)\end{array}$ & $\begin{array}{c}0.01 * * \\
(0.00)\end{array}$ & $\begin{array}{l}0.01 * * \\
(0.01)\end{array}$ \\
\hline $\begin{array}{l}\text { Party type (base: Christian } \\
\text { dems) }\end{array}$ & & & & & & \\
\hline Greens & $\begin{array}{c}0.14 \\
(1.16)\end{array}$ & $\begin{array}{l}-0.18 \\
(1.19)\end{array}$ & $\begin{array}{c}0.83 \\
(1.40)\end{array}$ & $\begin{array}{c}0.26 \\
(0.22)\end{array}$ & $\begin{array}{c}0.23 \\
(0.22)\end{array}$ & $\begin{array}{c}0.09 \\
(0.29)\end{array}$ \\
\hline Communists & $\begin{array}{c}-2.16^{* *} \\
(1.05)\end{array}$ & $\begin{array}{l}-2.10^{* *} \\
(1.00)\end{array}$ & $\begin{array}{l}-1.81 \\
(1.25)\end{array}$ & $\begin{array}{c}0.64 * * * \\
(0.18)\end{array}$ & $\begin{array}{c}0.66^{* * * *} \\
(0.18)\end{array}$ & $\begin{array}{l}0.57 * * \\
(0.23)\end{array}$ \\
\hline Social democrats & $\begin{array}{l}-0.13 \\
(0.65)\end{array}$ & $\begin{array}{l}-0.12 \\
(0.60)\end{array}$ & $\begin{array}{c}0.04 \\
(0.96)\end{array}$ & $\begin{array}{c}0.06 \\
(0.17)\end{array}$ & $\begin{array}{c}0.07 \\
(0.16)\end{array}$ & $\begin{array}{l}-0.05 \\
(0.10)\end{array}$ \\
\hline Liberals & $\begin{array}{l}-0.20 \\
(0.78)\end{array}$ & $\begin{array}{l}-0.40 \\
(0.76)\end{array}$ & $\begin{array}{c}3.15^{* * *} \\
(0.94)\end{array}$ & $\begin{array}{c}0.19 \\
(0.15)\end{array}$ & $\begin{array}{c}0.19 \\
(0.14)\end{array}$ & $\begin{array}{l}0.33^{*} \\
(0.17)\end{array}$ \\
\hline Conservatives & $\begin{array}{l}-0.43 \\
(0.57)\end{array}$ & $\begin{array}{l}-0.34 \\
(0.53)\end{array}$ & $\begin{array}{l}-0.40 \\
(0.59)\end{array}$ & $\begin{array}{c}0.01 \\
(0.12)\end{array}$ & $\begin{array}{c}0.01 \\
(0.12)\end{array}$ & $\begin{array}{l}-0.17 \\
(0.13)\end{array}$ \\
\hline Nationalists & $\begin{array}{l}-1.62 \\
(0.99)\end{array}$ & $\begin{array}{c}-1.58^{*} \\
(0.94)\end{array}$ & $\begin{array}{l}-1.47 \\
(1.15)\end{array}$ & $\begin{array}{l}-0.06 \\
(0.18)\end{array}$ & $\begin{array}{l}-0.04 \\
(0.18)\end{array}$ & $\begin{array}{l}-0.13 \\
(0.23)\end{array}$ \\
\hline
\end{tabular}




\begin{tabular}{lccc|ccc} 
Agrarians & - & - & $-3.49^{* *}$ & $0.49^{* *}$ & $0.46^{* *}$ & 0.33 \\
& $4.37^{* * *}$ & $4.66^{* * *}$ & & & & \\
Regional & $(1.32)$ & $(1.27)$ & $(1.60)$ & $(0.19)$ & $(0.19)$ & $(0.32)$ \\
& $-1.60^{*}$ & $-1.53^{*}$ & 1.34 & $0.27^{*}$ & $0.29^{*}$ & -0.28 \\
Niche-issue & $(0.94)$ & $(0.88)$ & $(1.80)$ & $(0.16)$ & $(0.15)$ & $(0.37)$ \\
& - & - & - & 0.19 & 0.20 & -0.19 \\
& $3.82^{* * *}$ & $3.79^{* * *}$ & $3.09^{* * *}$ & & & \\
DV (lag $t-1)$ & $(0.81)$ & $(0.78)$ & $(0.89)$ & $(0.14)$ & $(0.13)$ & $(0.18)$ \\
& -0.05 & -0.04 & -0.07 & -0.03 & -0.02 & 0.07 \\
Europhilia & $(0.07)$ & $(0.07)$ & $(0.08)$ & $(0.11)$ & $(0.11)$ & $(0.14)$ \\
& 0.01 & 0.00 & $0.02^{*}$ & 0.00 & -0.00 & -0.00 \\
ENEP & $(0.01)$ & $(0.01)$ & $(0.01)$ & $(0.00)$ & $(0.00)$ & $(0.00)$ \\
& -0.25 & -0.08 & $-0.51^{*}$ & -0.04 & -0.03 & -0.05 \\
Party FE & $(0.19)$ & $(0.18)$ & $(0.27)$ & $(0.03)$ & $(0.03)$ & $(0.05)$ \\
Year dummies & Yes & Yes & Yes & Yes & Yes & Yes \\
\hline Mean DV value & Yes & Yes & Yes & Yes & Yes & Yes \\
\hline Constant & $\mathbf{2 . 4 5}$ & $\mathbf{2 . 4 5}$ & $\mathbf{2 . 3 5}$ & $\mathbf{0 . 8 3}$ & $\mathbf{0 . 8 3}$ & $\mathbf{0 . 8 0}$ \\
& $2.22^{* *}$ & $1.79 * *$ & 2.18 & $0.46^{* *}$ & $0.40^{*}$ & 0.42 \\
Observations & $(0.93)$ & $(0.88)$ & $(1.34)$ & $(0.21)$ & $(0.22)$ & $(0.30)$ \\
R-squared & 339 & 339 & 194 & 271 & 271 & 154 \\
N parties & 0.80 & 0.82 & 0.83 & 0.58 & 0.59 & 0.58 \\
\hline
\end{tabular}

Panel-corrected standard errors (two-tailed) in parentheses $* * * \mathrm{p}<0.01, * * \mathrm{p}<0.05, * \mathrm{p}<0.1$

On average, there is no observable effect of substance or significance for EU intervention on clarity under any of the specifications (Models 9-11). There is a small positive effect observed in the case of misery: as economic hardships increased, parties became more likely to adopt a clearer position on their EU position.

\section{Party asymmetry}

To assess the effect of the explanatory variables across different family types, I run estimations using the model specification set out in Model 2, Model 6 and Model 9 using subsamples of party families. Figure 3 plots the coefficient of the main explements for each of the family types (full output in appendix). The left-hand panel depicts the effects on EU saliency. Of note, is that the negative effect of intervention appears to be driven by parties on the right. Given that intervened states observe a collapse of dimensional conflict over the EU and economic preferences (Katsanidou \& 
Otjes 2016; Otjes \& Katsanidou 2017), the suppression of EU politics amongst the right represents a rational strategic response for parties whose economic policy preferences are congruent with those demanded by the MoUs. Intervention exhibits almost no effect for social democrats and the far-left appears to decrease EU saliency but the significance of the effect falls short of conventional levels. The positive effect of the crisis in increasing EU saliency is also driven by the right, with the coefficient of misery, whilst positive, being indistinguishable from zero for both leftist party families.

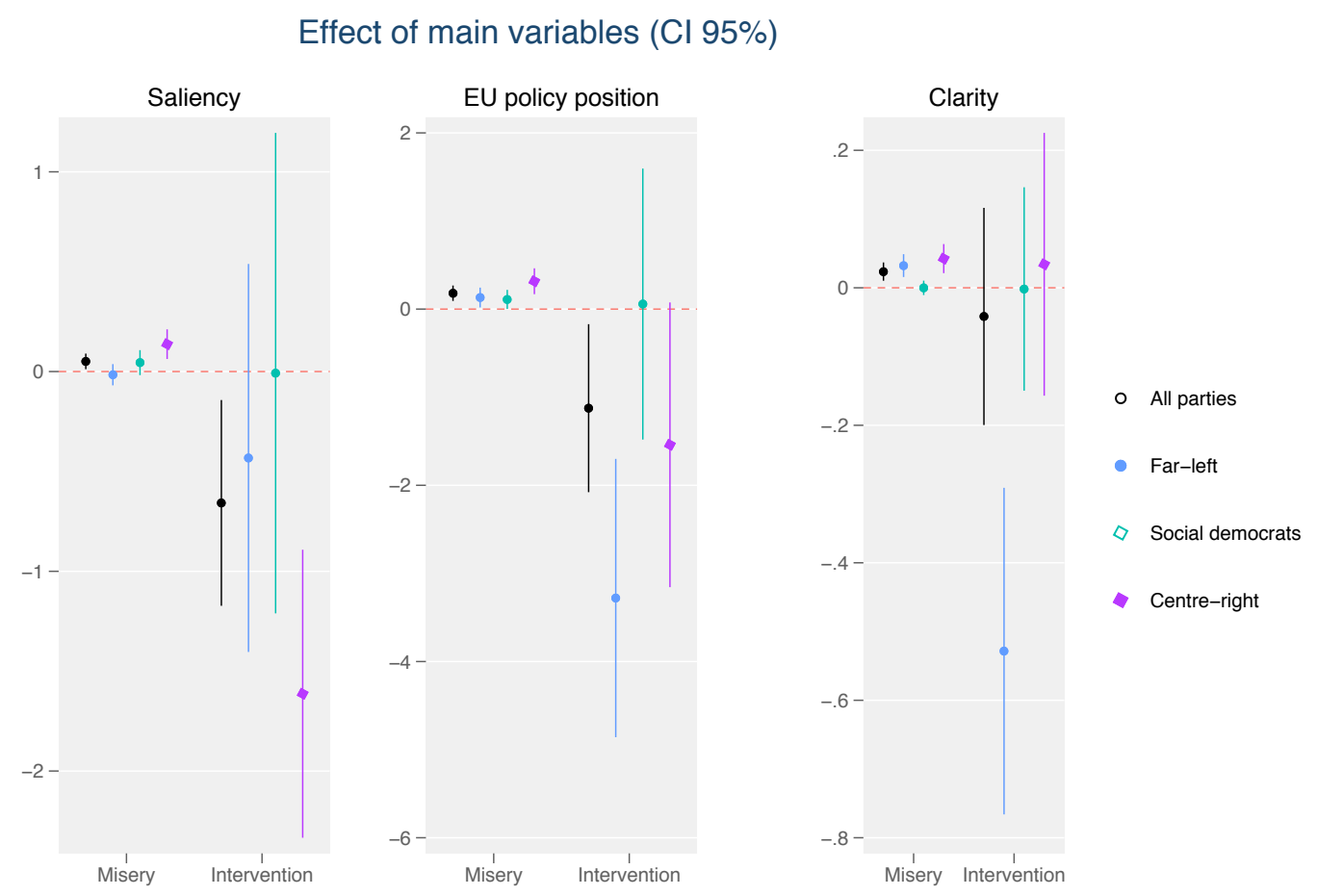

Figure 3: Asymmetric responsiveness of political parties

The central panel displays the effects on parties' EU positions and displays meaningful heterogeneity across parties. Increases in europhilia caused by the crisis appear to be a similar to all party types with misery exhibiting a small positive effect across the board. Notably, however, parties in intervened states on both the far-left and right move in the opposite direction, adopting significantly more eurosceptic policy positions. The 
eurosceptic shift of the far-left can be understood as an organic reaction by the bloc to EU-imposed austerity measures as the fiscal reforms demanded by the MoUs are ideologically polar to the economic preferences these parties advocate and is in line with the existing euro-critical tendencies amongst the far-left in comparison to the social democratic peers. ${ }^{\text {viii }}$ Although social democrats experience a positive association between economic hardship and a move toward europhilia, they do not appear to adapt their EU positions in any identifiable or systematic way in response to intervention.

The right-hand panel presents the effects on clarity. The results presented here suggest that null effects of intervention in the aggregated party was due to a lack of identifiable variation caused by grouping party types together. Parties on the far-left behave in a manner notably distinct from the two other types and increase the ambiguity of their EU positions in response to intervention. Economic misery has the opposite effect, increasing the clarity of the far-left's EU positions. This means that parties on the far-left become both explicitly more pro-EU in response to the crisis yet ambiguously more anti-EU as a result of the EU's economic constraints. Both social democratic and centre-right parties reduce the ambiguity of their positions with economic misery but there is no identifiable effect of note caused by intervention.

\section{Conclusion}

The findings of this paper shed new light on our understanding of the political consequences of the financial crisis and EU intervention on domestic politics. There is evidence that displays parties increase the level of EU politicisation as economic times are hard. This coincides with existing work that focuses on EU politicisation within the demand-side of electoral politics (Höglicher 2016; Hutter and Grande, 2014; Kriesi 2016; Leupold 2016). Here I show that mainstream parties, particularly those on the 
right, alter the saliency, position and clarity of their EU positions in both times of crisis and intervention. The outbreak of economic hardship engendered by the financial crisis is, on average, associated with a small, yet significant, increase in the saliency of the EU whilst also appears to push individual parties to become more europhile as well as clearer in their EU positions. Economic intervention, however, appears to have decreased the saliency of the EU and increased the ambiguity of parties' positions on the same, on average. It is also associated with a politically substantive and significant increase (decrease) in euroscepticism (europhilia).

Yet it is not the case that experiencing intervention exhibits a uniform effect over parties. In terms of saliency, left-leaning parties do not seem to display any marked changes, whilst the right displays a notable suppression of EU issues. The reverse appears to be the case for far-left parties who not only become more eurosceptic but also blur their positions. The right, in addition to substantially reducing EU saliency, become more eurosceptic but are not engaging in a blurring strategy as a result of intervention.

Focusing on the role of parties in responding to shifts in electoral awareness, demands and preferences relating to the EU, parties are found to respond in varied ways. Whilst the economic hardship is associated with a somewhat uniform effect on how parties compete over the EU; economic intervention is found to exhibit substantive and significant heterogeneous effects of parties' politicisation of Europe. This analysis leaves open a number of questions and suggests that social democratic parties have not been responsive to economic intervention by the EU. Given that parties on the left were electorally punished for agreeing to EU intervention far more than their right-wing competitors (Alsonso \& Ruíz-Rufino 2018) there are clear vote-seeking incentives for social democrats to politicise Europe. Is the unresponsiveness of social democratic 
parties the product of internal divisions, or is it the result of conflicting ideological motivations between opposition to the EU's austerity-promoting agenda and support for the European project itself? Rohrschneider and Whitefield (2016) may provide an answer in their argument that mainstream parties are restricted in their ability to react responsively to shifts in electoral demands based on Europe because of reputationalimperatives. The reputational restrictions against social democrats are likely not only concerned with how they are viewed by voters but also by supranational actors. Participation in government and interaction with the European apparatus socialises political operatives working within parties who are then less likely to oppose the consensus view of their European partners. It is clear, however, that additional work is needed to assess the non-response of social democratic parties to intervention.

The analysis presented here is not without its limitations. Of note is that the use of manifesto data as a means of testing the saliency of a specific policy dimension is not without its criticisms (Benoit et al. 2009) and may not reflect the issues that are the core subject of partisan communication within the wider noise of the election campaign. However, given both the high levels of politicisation on the demand-side within the electorate and the high threshold placed on manifestos to communicate policies that are most important to voters, relying on manifestos is an efficient means of tracing when parties are responsive to shifts in political conflict. The fact that the suppression of EU politics in intervened states is driven by parties on the right, whose ideological preferences on austerity are in sync with those associated with the MoUs, suggests that these parties are strategically reducing the scope for contestation over these same concerns and the reduction in EU saliency is not simply a methodological outcome of EU concerns being crowded out by other salient policy dimensions such as the economy. Indeed, if that were the case, one would most likely expect to see this in those 
parties with the most aggressive anti-austerity message (far-left parties) but these parties show no significant reduction in saliency associated with intervention.

Importantly, the analysis underscores the conditionality of the catalytic effect of the crisis in increasing partisan competition over the EU within domestic elections for non-intervened states. Unfortunately, for the citizens of the intervened states, this means that the two-tier level of constraints restraining the ability of parties to provide democratic choice, also constrains the amount of choice they are given regarding the constitutional shape and the policy output of the polity that applies the constraints. The resulting impact of intervention then as experienced so far has been to undermine democracy and restrict democratic choices not only in relation to economic output (Ruíz-Rufino \& Alonso 2017) but also in relation to Europe.

The EU, despite numerous institutional reforms to improve its democratic credentials (Schmidt 2013), has been plagued by persistent criticism regarding the lack of democratic legitimacy it is able to enjoy. One of the core arenas for providing the EU with legitimacy is the national electoral arena given that it is the national governments of member states that wield the most significant agenda-setting and polity-shaping power over the EU (Schmidt 2006). The lack of choice on Europe afforded to voters by parties in intervened states, alongside the increasing levels of domestic dissatisfaction in democracy experienced in these states' populations (Ruíz-Rufino \& Alonso 2017), is likely to do little to appease the critiques of democratic deficiency continuously made of the EU. Instead the negative effect of intervention in partisan offerings of choice on Europe will only add impetus to claims regarding the unresponsiveness of parties to the preferences of their voters (Rose 2014; Traber et al. 2018) in the context of increasing interstate dependence. 
i The twelve EMU states include: Austria, Belgium, Finland, France, Germany, Greece, Ireland, Italy, Luxembourg, Netherlands, Portugal, and Spain.

ii Greece and Ireland signed MoUs in 2010. Portugal signed a MoU in 2011. Spain and Italy were advised by the ECB they were required to implement an austerity package in 2011 should they wish to be considered for financial assistance in the future (both complied). Spain signed a MoU-like agreement in 2012 in exchange for capital for country's struggling banks. Cyprus signed a MoU in 2013 but is not included in the twelve states in the analysis.

iii A manifesto would have a clarity score of 0 if its pro- and anti-EU statements were perfectly balanced (Adams et al., 2017) or 1 if its statements were 100\% unidirectional.

iv Gov. debt as percentage of GDP. Data for macroeconomic indicators taken from the Comparative Political Data Set 1960-2016 (Armingeon, et al. 2018). Data for the 2017 elections was taken from Eurostat.

${ }^{\mathrm{v}}$ In cases of coalition government, the main coalition partner.

vi All parties included in MARPOR are incorporated into the models but only left, social democrat and right parties are used as subsample categories. Methodologically, I am unable to run subsample estimations based on each of the unique family codes in the dataset because of the very low number of certain family types in the data or because of lack of variation in these types over some of the main explanatory variables. Theoretically, ecological and communist countries tend to cluster around the same liberal-left political space (Whitefield and Rohrschneider 2019) so their ideological motivations in relation to Europe are likely to be in sync too. Grouping these parties together allows for the differentiation between parties whilst still facilitating a sufficient number of observations to allow for the application of the necessary estimation techniques.

vii Additional estimations in appendix. Despite the hierarchical data structure of parties and countries, multilevel modelling is inappropriate given the small $\mathrm{N}$ of higher-level observations (Bickel 2007). 
viii The mean EU position of far-left parties is significantly more eurosceptic (0.86) compared to social democrats (2.77) and those on the right (2.25). See Table A4. 


\section{Bibliography}

Adams, James, et al. (2014). 'Do Voters Respond to Party Manifestos or to a Wider Information Environment? An Analysis of Mass-Elite Linkages on European Integration, American Journal of Political Science, 58:4, 967-978.

Adams, James, et al. (2011). 'Is Anybody Listening? Evidence That Voters Do Not Respond to European Parties' Policy Statements During Elections', American Journal of Political Science, 55:2, 370-382.

Adam, Silke, et al. (2017). 'Strategies of pro-European parties in the face of a Eurosceptic challenge', European Union Politics, 18:2, 260-282.

Almeida, Dimitri (2012). The Impact of European Integration on Political Parties. Beyond the Permissive Consensus. London: Routledge.

Alonso, Sonia (2014). "You can vote but you cannot choose": Democracy and the Sovereign Debt Crisis in the Eurozone', Working paper 2014/282, Instituto Carlos III - Juan March de Ciencias Sociales

Alonso, Sonia, and Rubén Ruíz-Rufino (2018). 'The Costs of Responsibility for the Political Establishment of the Eurozone (1999-2015)', Party Politics. https://doi.org/10.1177/1354068818766182

Beck, Nathaniel, and Jonathan N Katz (1995). 'What to do (and not to do) with timeseries cross-section data', American Political Science Review, 89:3, 634-647. 
Benoit, Ken, Michael Laver and Slavia Mikhaylov (2009). 'Treating Words as Data with Error: Uncertainty in Text Statements of Policy Positions', American Journal of Political Science, 53:2, 495-513.

Bickel, Robert (2007). Multilevel Analysis for Applied Research. New York: Guilford Press.

Blyth, Mark (2013). Austerity: The History of a Dangerous Idea. Oxford: Oxford University Press.

Börzel, Tanja (2016). 'From EU Governance of Crisis to Crisis of EU Governance: Regulatory Failure, Redistributive Conflict and Eurosceptic Publics', Journal of Common Market Studies, 54, 8-31.

Bosco, Anna, and Susannah Verney (2012). 'Electoral Epidemic: The Political Cost of Economic Crisis in Southern Europe, 2010-11', South European Society and Politics, $17: 2,129-154$.

Braun, Daniela, Sebastian Popa, and Hermann Schmitt (2019). 'Responding to the crisis: Eurosceptic parties of the left and right and their changing position towards the European Union', European Journal of Political Research. https://doi.org/10.1111/1475$\underline{6765.12321}$ 
Charalambous, Giorgos, Nicolò Conti and Andrea Pedrazzani (2018). 'The political contestation of European integration in Southern Europe. Friction among and within parties', Party Politics, 24:1, 39-51.

Copelovitch, Mark, Jeffry Frieden and Stefanie Walker (2016). 'The Political Economy of the Euro Crisis', Comparative Political Studies, 49:7, 811-840.

Carrubba, Clifford (2001). 'The Electoral Connection in European Union Politics', Journal of Politics, 63:1, 141-158.

DeVries, Catherine E (2018). Euroscepticism and the Future of European Integration. Oxford: Oxford University Press.

DeVries, Catherine E (2007). 'Sleeping Giant: Fact or Fairytale? How European Integration Affects National Election', European Union Politics, 8:3, 363-385.

DeVries, Catherine E, and Sara Hobolt (2012). 'When dimensions collide: The electoral success of issue entrepreneurs', European Union Politics, 13:2, 246-268.

De Wilde, Pieter, Anna Leupold and Henning Schmidtke (2016). 'Introduction: the differentiated politicisation of European governance', West European Politics, 39:1, 3-22

De Wilde, Pieter, and Micahel Zürn (2012). 'Can the Politicization of European Integration Be Reversed?', Journal of Common Market Studies, 50, 137-153. 
Dolezal, Martin, et al. (2012). 'The Life Cycle of Party Manifestos: The Austrian Case', West European Politics 35:4, 869-895.

Downs, Anthony (1957). An Economic Theory of Democracy. New York: Harper.

Eder, Nikolaus, Marcelo Jenny and Wolfgang C. Müller (2017). 'Manifesto functions: How party candidates view and use their party's central policy document', Electoral Studies, $45,75-87$.

Follesdal, Andreas, and Simon Hix (2006). 'Why There Is a Democratic Deficit in the EU: A Response to Majone and Marovcsik', Journal of Common Market Studies, 44:3, 533562.

Gifford, Christopher (2014). 'The People Against Europe: The Eurosceptic Challenge to the United Kingdom's Coalition Government', Journal of Common Market Studies, 52:3, $512-528$.

Grande, Edgar, and Swen Hutter (2016). 'Beyond authority transfer: explaining the politicisation of the Europe', West European Politics, 39:1, 23-43.

Green-Pederson, Christoffer (2012). 'A Giant Fast Asleep? Party Incentives and the Politicisation of European Integration', Political Studies, 60:1, 115-130.

Hall, Peter A (2014). 'Varieties of Capitalism and the Euro Crisis', West European Politics, 37:6, 1123-1243. 
Haupt, Andrea B (2010). 'Parties' Responses to Economic Globalization: What is Left for the Left and Right for the Right?', Party Politics, 16:1, 5-27.

Hellström, Johan, and Magnus Blomgren (2016). 'Party debate over Europe in national election campaigns: Electoral disunity and party cohesion', European Journal of Political Research, 55:2, 265-282.

Hernandez, Enrique, and Hanspeter Kriesi (2016). 'The Electoral Consequences of the Financial and Economic Crisis in Europe', European Journal of Political Research 55:2, 203-224.

Hix, Simon (2008). What's Wrong with the European Union and How to Fix it. Cambridge: Polity Press.

Hobolt, Sara B, and Catherine E De Vries (2016). 'Public Support for European Integration', Annual Review of Political Science, 19, 413-432.

Hobolt, Sara B, and James Tilley (2016). 'Fleeing the centre: the rise of challenger parties in the aftermath of the euro crisis', West European Politics, 39:5, 971-991.

Hobolt, Sara B, and James Tilley (2014). Blaming Europe? Responsibility without Accountability in the European Union. Oxford: Oxford University Press. 
Höglinger, Dominic (2016). Politicizing European Integration. Struggling with the Awakening Giant. Basingstoke: Palgrave Macmillan.

Hooghe, Lisbet, Gary Marks and Carole J Wilson (2002). 'Does left/right structure party positions on European integration?' Comparative Political Studies, 35:8, 965-989.

Hooghe, Lisbet, and Gary Marks (2009). 'A postfunctionlist theory of European integration: From permissive consensus to constraining dissensus', British Journal of Political Science 39:1, 1-23.

Hooghe, Lisbet, and Gary Marks (2018). 'Cleavage theory meets Europe's crises: Lipset, Rokkan and the transnational cleavage', Journal of European Public Policy, 25:1, 109-135.

Hutter, Swen, and Edgar Grande (2014). 'Politicizing Europe in the National Electoral Arena: A Comparative Analysis of Five West European Countries, 1970-2010', Journal of Common Market Studies, 52:5, 1002-1018.

Hutter, Swen, Edgar Grande and Hanspeter Kriesi (eds.), (2016). Politicising Europe: Integration and Mass Politics. Cambridge: Cambridge University Press.

Hutter, Swen, Hanspeter Kriesi and Guillem Vidal (2018). 'Old versus new politics: The political spaces in Southern Europe in times of crisis', Party Politics, 24:1, 10-22. 
Hutter, Swen, and Hanspeter Krieisi (2019). 'Politicizing Europe in times of crisis', European Journal of Public Policy. https://doi.org/10.1080/13501763.2019.1619801

Katsanidou, Alexia, and Simon Otjes (2016). 'How the European debt crisis reshaped national political space: The case of Greece', European Union Politics, 17:2, 262-284.

Kriesi, Hanspeter (2007). 'The role of European integration in national election campaigns', European Union Politics, 8:1, 83-108.

Kriesi, Hanspeter, and Takis S Pappas (eds.), (2015). European Populism in the Shadow of the Great Recession. Colchester: ECPR Press.

Külahci, Erol (ed.), (2012). Europeanisation and Party Politics. Colchester: ECPR Press.

Ladrech, Robert (2002). 'Europeanization and Political Parties: Towards A Framework for Analysis', Party Politics, 8:4, 389-403.

Leupold, Anna (2016). 'A structural approach to politicisation in the Euro crisis', West European Politics, 39:1, 84-103.

Lowe, Will, et al. (2011). 'Scaling Policy Preferences from Coded Political Texts', Legislative Studies Quarterly, 36:1, 123-155. 
Magone, José M (2016). 'From 'superficial' to 'coercive' europeanisation in Southern Europe', in José M Magone, Brigid Laffan and Christian Schweiger (eds.), Power and Conflict in a Dualist Economy. London: Routledge, 87-98.

Mair, Peter (2000). 'The limited impact of Europe on national party systems', West European Politics, 23, 27-51.

Mair, Peter (2009). 'Representative versus Responsible Government', MPLfG Working Papers. August 2009.

Mair, Peter (2013). Ruling the Void: The Hollowing of Western Democracy. London: Verso.

Meijers, Maurits J (2017). 'Contagious Euroscepticism: The impact of Eurosceptic support on mainstream party positions on European integration', Party Politics 23:4, 413423.

Otjes, Simon, and Alexia Katsanidou (2017). 'Beyond Kriesiland: EU integration as a super issue after the Eurocrisis', European Journal of Political Research, 56:2, 301-319.

Pennings, Paul (2006). 'An Empirical Analysis of the Europeanization of National Party Manifestos, 1960 - 2003', European Union Politics, 7:2, 257-270. 
Polk, Jonathan, et al. (2017) 'Explaining the salience of anti-elitism and reducing political corruption for political parties in Europe with the 2014 Chapel Hill Expert Survey data', Research \& Politics, 4:1, 1-8.

Reif, Karlheinz, and Hermann Schmitt (1980). 'Nine Second-order National Elections - A Conceptual Framework for the Analysis of European Election Results', European Journal of Political Research 8:1, 3-44.

Rohrschneider, Robert and Stephen Whitefield (2016). 'Responding to growing European Union-skepticism? The stances of political parties toward European integration in Western and Eastern Europe following the financial crisis', European Union Politics, 17:1, $138-161$.

Rose, Richard (2014). 'Responsible party government in a world of interdependence', West European Politics 37:2, 253-269.

Rovny, Jan (2012). 'Who emphasizes and who blurs? Party strategies in multidimensional competition', European Union Politics 13:2, 269-292.

Ruíz-Rufino, Rubén, and Sonia Alonso (2017). 'Democracy without choice: Citizens' perceptions of government autonomy during the Eurozone crisis', European Journal of Political Research, 56:2, 320-334.

Scharpf, Fritz W (1999). Governing in Europe: Effective and democratic? Oxford: Oxford University Press. 
Schmidt, Vivien A (2013). 'Democracy and Legitimacy in the European Union Revisited: Input, Output and 'Throughput'. Political Studies 61:1, 2-22.

Schmidt, Vivien A (2006) Democracy in Europe, The EU and National Polities. Oxford: Oxford University Press.

Schmitt, Herman, and Jacques Thomassen (2000). 'Dynamic Representation: The Case of the European Union', European Union Politics, 1:3, 318-339.

Spoon, Jae-Jae, and Christopher Williams (2017). 'It takes two: how Eurosceptic public opinion and party divisions influence party positions', West European Politics, 40:4, $741-762$.

Statham, Paul, and Hans-Jörg Trenz (2013). The Politicization of Europe: Contesting the Constitution in the Mass Media. Abingdon: Routledge.

Statham, Paul, and Hans-Jörg Trenz (2015). 'Understanding the Mechanisms of EU Politicization: Lessons from the Eurozone Crisis', Comparative European Politics 13:3, 287306.

Steenbergen, Marco R, Erica E Edwards and Catherine E De Vries (2007). 'Who's Cueing Whom?: Mass-Elite Linkages and the Future of European Integration,' European Union Politics, 8:1, 13-35. 
Strøm, Kaare (1990). 'A Behavioural Theory of Competitive Political Parties,' American Journal of Political Science, 34:2, 565-598.

Taggart, Paul (1998). 'A Touchstone of Dissent: Euroscepticism in Contemporary Western European Party Systems', European Journal of Political Research, 33:3, 363-388.

Traber, Denise, Nathalie Giger and Silja Häusermann (2018). 'How economic crises affect political representation: declining party-voter congruence in times of constrained government', West European Politics 41:5, 1100-1124.

Van Aelst, Peter, et al. (2008). 'Politicians in the news: Media or party logic? Media attention and electoral success in the Belgian election campaign of 2003', European Journal of Communication, 23:2, 193-210.

Van Dalen, Arjen (2012). 'Structural bias in cross-national perspective: How political systems and journalism cultures influence government dominance in the news', The International Journal of Press/Politics, 17:1, 32-55.

Whitefield, Stephen, and Robert Rohrschneider (2019). 'Embedding integration: How European integration splits mainstream parties', Party Politics, 25:1, 25-35.

Zürn, Michael (2019). 'Politicization compared: at national, European, and global levels', Journal of European Public Policy, 26:7, 977-995. 


\section{$\underline{\text { Appendix }}$}

Table A 1: Country and elections included in analysis

\begin{tabular}{ll}
\hline Country & Elections \\
\hline Austria (5) & $2002,2006,2008,2013,2017$ \\
Belgium (3) & $2003,2007,2010$ \\
\hline Finland (3) & $2003,2007,2011$ \\
\hline France (4) & $2002,2007,2012,2017$ \\
Germany (5) & $2002,2005,2009,2013,2017$ \\
Greece (5) & $2004,2007,2009,2012,2015$ \\
Ireland (4) & $2002,2007,2011,2016$ \\
Italy (3) & $2006,2008,2013$ \\
\hline Luxembourg (3) & $2004,2009,2013$ \\
Netherlands (6) & $2002,2003,2006,2010,2012,2017$ \\
Portugal (4) & $2002,2005,2009,2011$ \\
Spain (5) & $2004,2008,2011,2015,2016$ \\
\hline
\end{tabular}

Table A 2: Summary statistics

\begin{tabular}{lrrrrr}
\hline Variable & Observations & Mean & SD & Min & Max \\
\hline Saliency & 339 & -3.806 & 0.950 & -7.738 & -1.597 \\
EU position & 339 & 1.498 & 2.445 & -5.043 & 6.176 \\
Clarity & 302 & 0.831 & 0.257 & 0.024 & 1.000 \\
Economic misery & 339 & 0.752 & 4.615 & -13.801 & 18.530 \\
Party size & 339 & 13.691 & 12.673 & 0.000 & 46.396 \\
Europhilia & 339 & 29.227 & 20.112 & -6.477 & 109.954 \\
ENEP & 339 & 4.774 & 1.777 & 2.412 & 9.130 \\
\hline
\end{tabular}

\section{Operationalisation of dependent variables}

- EU saliency can be defined as follows:

$$
E S=\log \frac{S_{p_{\text {pos }}+S_{n e g}+1}}{N}
$$

Where ES indicates saliency of the EU and $S_{p o s}$ and $S_{\text {neg }}$ indicate the number of quasisentences in the manifesto dedicated to positive and negative stances on EU integration respectively.

- EU position is defined as follows:

$$
P=\log \left(S_{\text {pos }}+0.5\right)-\log \left(S_{\text {neg }}+0.5\right)
$$

Where $P$ indicates a party's overall EU position

- Both ES and P are calculated following recommendation of Lowe et al. (2011). 
- Clarity $(\mathrm{C})$ is defined as the absolute value of the following and indicates a clarity score running from 0 (completely blurred position with equal number of quasisentences in favour of / opposed to policy) to 1 (unambiguously in favour of / opposed to policy): $C=\frac{S_{p o s}-S_{n e g}}{S_{p o s}+S_{n e g}}$

\section{Understanding clarity.}

Say for example a party made 20 EU+ comments and 10 EU- comments. They're EU position, as measured by the CMP would be 10 . The clarity of that position would be 0.33 . Say for example another party makes $10+$ EU comments and 0 EU- comments. They're EU position would be also be 10 but the clarity of their position would be 1 as they have been unambiguously pro-european in their messaging.

Table A 3: Principal component analysis (unrotated)

\begin{tabular}{l|l|l}
\hline Variable & Factor I & Uniqueness \\
\hline Unemployment & 0.8647 & 0.2524 \\
\hline Public debt & 0.8533 & 0.2719 \\
\hline GDP & -.7512 & 0.4357 \\
\hline
\end{tabular}


Table A 4: Asymmetric party effects

\begin{tabular}{|c|c|c|c|c|c|c|c|c|c|}
\hline & \multicolumn{3}{|c|}{ EU saliency } & \multicolumn{3}{|c|}{ EU position } & \multicolumn{3}{|c|}{ Position clarity } \\
\hline & (Left) & $(\mathrm{SD})$ & (Right) & (Left) & (SD) & (Right) & (Left) & $(\mathrm{SD})$ & (Right) \\
\hline Misery & $\begin{array}{l}-0.02 \\
(0.03)\end{array}$ & $\begin{array}{c}0.04 \\
(0.03)\end{array}$ & $\begin{array}{c}0.14^{* * *} \\
(0.04)\end{array}$ & $\begin{array}{l}0.13^{* *} \\
(0.06)\end{array}$ & $\begin{array}{l}0.11^{* *} \\
(0.06)\end{array}$ & $\begin{array}{c}0.32^{* * * *} \\
(0.07)\end{array}$ & $\begin{array}{c}0.03^{* * *} \\
(0.01)\end{array}$ & $\begin{array}{l}-0.00 \\
(0.01)\end{array}$ & $\begin{array}{c}0.04 * * * \\
(0.01)\end{array}$ \\
\hline Intervention & $\begin{array}{l}-0.43 \\
(0.50)\end{array}$ & $\begin{array}{l}-0.01 \\
(0.61)\end{array}$ & $\begin{array}{c}-1.61 * * * \\
(0.37)\end{array}$ & $\begin{array}{c}-3.28 * * * \\
(0.81)\end{array}$ & $\begin{array}{c}0.06 \\
(0.78)\end{array}$ & $\begin{array}{l}-1.54^{*} \\
(0.82)\end{array}$ & $\begin{array}{c}-0.53 * * * \\
(0.12)\end{array}$ & $\begin{array}{l}-0.00 \\
(0.08)\end{array}$ & $\begin{array}{c}0.03 \\
(0.10)\end{array}$ \\
\hline Incumbency & & $\begin{array}{l}0.51^{* *} \\
(0.23)\end{array}$ & $\begin{array}{c}0.13 \\
(0.20)\end{array}$ & & $\begin{array}{c}0.35 \\
(0.39)\end{array}$ & $\begin{array}{c}0.60 \\
(0.38)\end{array}$ & & $\begin{array}{c}0.02 \\
(0.04)\end{array}$ & $\begin{array}{l}0.13 * * \\
(0.06)\end{array}$ \\
\hline Party size & $\begin{array}{c}0.01 \\
(0.03)\end{array}$ & $\begin{array}{c}-0.04 * * \\
(0.02)\end{array}$ & $\begin{array}{l}-0.02 \\
(0.01)\end{array}$ & $\begin{array}{l}0.12^{* *} \\
(0.06)\end{array}$ & $\begin{array}{l}-0.00 \\
(0.02)\end{array}$ & $\begin{array}{l}-0.03 \\
(0.03)\end{array}$ & $\begin{array}{c}0.00 \\
(0.01)\end{array}$ & $\begin{array}{c}0.00 \\
(0.00)\end{array}$ & $\begin{array}{c}-0.01 * * \\
(0.00)\end{array}$ \\
\hline Saliency lag & $\begin{array}{c}-0.36^{* * *} \\
(0.12)\end{array}$ & $\begin{array}{c}-0.32 * * \\
(0.15)\end{array}$ & $\begin{array}{c}-0.20^{* *} \\
(0.10)\end{array}$ & & & & & & \\
\hline Position lag & & & & $\begin{array}{l}-0.00 \\
(0.12)\end{array}$ & $\begin{array}{c}-0.40^{* * *} \\
(0.16)\end{array}$ & $\begin{array}{l}-0.01 \\
(0.15)\end{array}$ & & & \\
\hline Clarity lag & & & & & & & $\begin{array}{l}-0.08 \\
(0.21)\end{array}$ & $\begin{array}{l}-0.00 \\
(0.15)\end{array}$ & $\begin{array}{c}0.06 \\
(0.17)\end{array}$ \\
\hline Europhilia & $\begin{array}{c}-0.02 * * * \\
(0.00)\end{array}$ & $\begin{array}{l}-0.01 \\
(0.01)\end{array}$ & $\begin{array}{l}-0.01 * \\
(0.00)\end{array}$ & $\begin{array}{c}-0.03 * * \\
(0.01)\end{array}$ & $\begin{array}{c}0.01 \\
(0.01)\end{array}$ & $\begin{array}{l}0.02^{*} \\
(0.01)\end{array}$ & $\begin{array}{l}-0.00 \\
(0.00)\end{array}$ & $\begin{array}{l}-0.00 \\
(0.00)\end{array}$ & $\begin{array}{l}0.00^{*} \\
(0.00)\end{array}$ \\
\hline ENEP & $\begin{array}{c}0.20 \\
(0.15)\end{array}$ & $\begin{array}{l}-0.14 \\
(0.16)\end{array}$ & $\begin{array}{l}0.24^{*} \\
(0.15)\end{array}$ & $\begin{array}{l}-0.30 \\
(0.29)\end{array}$ & $\begin{array}{c}-0.89 * * * \\
(0.23)\end{array}$ & $\begin{array}{l}-0.42 \\
(0.26)\end{array}$ & $\begin{array}{l}-0.01 \\
(0.03)\end{array}$ & $\begin{array}{l}-0.03 \\
(0.03)\end{array}$ & $\begin{array}{l}-0.00 \\
(0.05)\end{array}$ \\
\hline Party FE & Yes & Yes & Yes & Yes & Yes & Yes & Yes & Yes & Yes \\
\hline Year dummies & Yes & Yes & Yes & Yes & Yes & Yes & Yes & Yes & Yes \\
\hline Mean DV value & -3.62 & -3.82 & -3.86 & 0.82 & 2.77 & 2.25 & 0.84 & 0.90 & 0.81 \\
\hline Constant & $\begin{array}{c}-6.98 * * * \\
(1.40)\end{array}$ & $\begin{array}{c}-4.05 * * * \\
(1.41)\end{array}$ & $\begin{array}{c}-5.55^{* * *} \\
(1.04)\end{array}$ & $\begin{array}{c}1.19 \\
(1.98)\end{array}$ & $\begin{array}{c}6.52 * * * \\
(1.47)\end{array}$ & $\begin{array}{c}1.72 \\
(1.62)\end{array}$ & $\begin{array}{l}0.46^{* *} \\
(0.20)\end{array}$ & $\begin{array}{c}0.90^{* * * *} \\
(0.30)\end{array}$ & $\begin{array}{c}0.52 \\
(0.41)\end{array}$ \\
\hline Observations & 91 & 54 & 76 & 91 & 54 & 76 & 69 & 46 & 56 \\
\hline R-squared & 0.72 & 0.71 & 0.79 & 0.90 & 0.79 & 0.75 & 0.79 & 0.78 & 0.85 \\
\hline $\mathrm{N}$ parties & 30 & 14 & 21 & 30 & 14 & 21 & 27 & 11 & 19 \\
\hline
\end{tabular}

\section{main mode}

Panel-corrected standard errors in parentheses $* * * \mathrm{p}<0.01,{ }^{* *} \mathrm{p}<0.05,{ }^{*} \mathrm{p}<0.1$

$(0.10)$

$0.06)$

$00)$ 
Table A 5: Asymmetric party effects (interaction model)

\begin{tabular}{|c|c|c|c|c|c|c|c|c|c|}
\hline & \multicolumn{3}{|c|}{ EU saliency } & \multicolumn{3}{|c|}{ EU position } & \multicolumn{3}{|c|}{ Position clarity } \\
\hline & (Left) & $(\mathrm{SD})$ & (Right) & (Left) & (SD) & (Right) & (Left) & (SD) & (Right) \\
\hline Misery & $\begin{array}{l}0.07 * * \\
(0.03)\end{array}$ & $\begin{array}{l}0.10^{* *} \\
(0.04)\end{array}$ & $\begin{array}{l}0.11^{* *} \\
(0.05)\end{array}$ & $\begin{array}{c}0.27 * * * \\
(0.06)\end{array}$ & $\begin{array}{c}0.20 * * * \\
(0.06)\end{array}$ & $\begin{array}{c}0.50 * * * \\
(0.07)\end{array}$ & $\begin{array}{c}0.03 * * * \\
(0.01)\end{array}$ & $\begin{array}{c}0.01 \\
(0.01)\end{array}$ & $\begin{array}{c}0.06^{* * * *} \\
(0.01)\end{array}$ \\
\hline Intervention & $\begin{array}{c}0.95 \\
(0.61)\end{array}$ & $\begin{array}{c}0.95 \\
(0.71)\end{array}$ & $\begin{array}{c}-1.90 * * * \\
(0.48)\end{array}$ & $\begin{array}{l}-1.19 \\
(1.07)\end{array}$ & $\begin{array}{c}1.76 \\
(1.08)\end{array}$ & $\begin{array}{l}0.50 \\
(0.96)\end{array}$ & $\begin{array}{c}-0.52 * * * \\
(0.16)\end{array}$ & $\begin{array}{c}0.17 \\
(0.10)\end{array}$ & $\begin{array}{c}0.41 * * * \\
(0.15)\end{array}$ \\
\hline Interaction & $\begin{array}{c}-0.19 * * * \\
(0.05)\end{array}$ & $\begin{array}{c}-0.14^{* *} \\
(0.06)\end{array}$ & $\begin{array}{c}0.06 \\
(0.06)\end{array}$ & $\begin{array}{c}-0.30 * * * \\
(0.10)\end{array}$ & $\begin{array}{c}-0.22^{* *} \\
(0.09)\end{array}$ & $\begin{array}{c}-0.40^{* * *} \\
(0.10)\end{array}$ & $\begin{array}{l}-0.00 \\
(0.02)\end{array}$ & $\begin{array}{l}-0.02^{*} \\
(0.01)\end{array}$ & $\begin{array}{c}-0.09^{* * * *} \\
(0.02)\end{array}$ \\
\hline Incumbency & & $\begin{array}{c}0.51^{* *} \\
(0.23)\end{array}$ & $\begin{array}{c}0.12 \\
(0.20)\end{array}$ & & $\begin{array}{c}0.36 \\
(0.35)\end{array}$ & $\begin{array}{l}0.66^{* *} \\
(0.33)\end{array}$ & & $\begin{array}{c}0.02 \\
(0.03)\end{array}$ & $\begin{array}{c}0.16^{* * * *} \\
(0.05)\end{array}$ \\
\hline Party size & $\begin{array}{c}0.03 \\
(0.02)\end{array}$ & $\begin{array}{c}-0.04 * * \\
(0.02)\end{array}$ & $\begin{array}{l}-0.02 \\
(0.01)\end{array}$ & $\begin{array}{c}0.15^{* *} \\
(0.06)\end{array}$ & $\begin{array}{l}-0.00 \\
(0.02)\end{array}$ & $\begin{array}{c}-0.06^{* *} \\
(0.02)\end{array}$ & $\begin{array}{c}0.00 \\
(0.01)\end{array}$ & $\begin{array}{c}0.00 \\
(0.00)\end{array}$ & $\begin{array}{c}-0.01 * * * \\
(0.00)\end{array}$ \\
\hline Saliency lag & $\begin{array}{c}-0.30 * * * \\
(0.10)\end{array}$ & $\begin{array}{c}-0.36^{* *} \\
(0.15)\end{array}$ & $\begin{array}{l}-0.04 \\
(0.09)\end{array}$ & & & & & & \\
\hline Position lag & & & & $\begin{array}{c}0.06 \\
(0.12)\end{array}$ & $\begin{array}{c}-0.46^{* * *} \\
(0.15)\end{array}$ & $\begin{array}{c}0.01 \\
(0.14)\end{array}$ & & & \\
\hline Clarity lag & & & & & & & $\begin{array}{l}-0.08 \\
(0.20)\end{array}$ & $\begin{array}{l}-0.06 \\
(0.15)\end{array}$ & $\begin{array}{l}-0.01 \\
(0.16)\end{array}$ \\
\hline Europhilia & $\begin{array}{c}-0.02 * * * \\
(0.00)\end{array}$ & $\begin{array}{l}-0.01 \\
(0.01)\end{array}$ & $\begin{array}{l}-0.01 * \\
(0.00)\end{array}$ & $\begin{array}{c}-0.03 * * * \\
(0.01)\end{array}$ & $\begin{array}{c}0.01 \\
(0.01)\end{array}$ & $\begin{array}{c}0.02 \\
(0.01)\end{array}$ & $\begin{array}{l}-0.00 \\
(0.00)\end{array}$ & $\begin{array}{l}-0.00 \\
(0.00)\end{array}$ & $\begin{array}{l}0.00^{*} \\
(0.00)\end{array}$ \\
\hline ENEP & $\begin{array}{l}0.29 * * \\
(0.15)\end{array}$ & $\begin{array}{l}-0.07 \\
(0.15)\end{array}$ & $\begin{array}{c}0.21 \\
(0.14)\end{array}$ & $\begin{array}{l}-0.11 \\
(0.28)\end{array}$ & $\begin{array}{c}-0.82 * * * \\
(0.22)\end{array}$ & $\begin{array}{l}-0.17 \\
(0.26)\end{array}$ & $\begin{array}{l}-0.01 \\
(0.03)\end{array}$ & $\begin{array}{l}-0.03 \\
(0.02)\end{array}$ & $\begin{array}{l}-0.05 \\
(0.04)\end{array}$ \\
\hline Party FE & Yes & Yes & Yes & Yes & Yes & Yes & Yes & Yes & Yes \\
\hline Year dummies & Yes & Yes & Yes & Yes & Yes & Yes & Yes & Yes & Yes \\
\hline Mean DV value & -3.62 & -3.82 & -3.86 & 0.82 & 2.77 & 2.25 & 0.84 & 0.90 & 0.81 \\
\hline Constant & $\begin{array}{c}-7.10 * * * \\
(1.30)\end{array}$ & $\begin{array}{c}-4.67 * * * \\
(1.27)\end{array}$ & $\begin{array}{c}-5.40 * * * \\
(1.03)\end{array}$ & $\begin{array}{c}0.24 \\
(1.95)\end{array}$ & $\begin{array}{c}6.34 * * * \\
(1.44)\end{array}$ & $\begin{array}{c}0.49 \\
(1.60)\end{array}$ & $\begin{array}{l}0.46^{* *} \\
(0.21)\end{array}$ & $\begin{array}{c}0.95^{* * * *} \\
(0.29)\end{array}$ & $\begin{array}{l}0.86^{* *} \\
(0.35)\end{array}$ \\
\hline Observations & 91 & 54 & 76 & 91 & 54 & 76 & 69 & 46 & 56 \\
\hline
\end{tabular}




\begin{tabular}{lccc|ccc|ccc} 
R-squared & 0.76 & 0.74 & 0.80 & 0.91 & 0.81 & 0.80 & 0.79 & 0.79 & 0.88 \\
$\mathrm{~N}$ parties & 30 & 14 & 21 & 30 & 14 & 21 & 27 & 11 & 19 \\
\hline
\end{tabular}

Panel-corrected standard errors in parentheses *** $\mathrm{p}<0.01, * * \mathrm{p}<0.05, * \mathrm{p}<0.1$ 


\section{Robustness checks.}

The use of the Beck and Katz (1995) is the most effective estimation technique given that it controls for the potential for autocorrelation and heteroscedastic errors it suffers from the fact that including observational unit (in this case party) fixed effects means that much of the variation is explained away via these fixed effects. Below the models are estimated to using different variations of fixed effects. Whilst the results below will likely suffer from the errors Beck and Katz warn against, they are shown here to highlight that even when I remove the observational unit effects, the main explanatory variables retain their effect. In Table 4A I continue using the PCSE models. In Table $5 \mathrm{~A}$, panel fixed-effects are included. Using panel fixed effects estimation method, however, forces me to remove time-invariant variables which (whilst controlled for the in the model via the panel set up) cannot be isolated. In both robustness checks, the dependent variable is EU saliency.

The results of these additional tests serve to confirm the main conclusion and show that the main findings are not conditional on the estimation technique applied and are echoed across different, if, however, less efficient methods. Economic misery still drives EU saliency amongst non-intervened states whilst exposure to EU intervention decreases EU saliency. 
Table A 6: PCSE models using different fixed effects

\begin{tabular}{|c|c|c|c|c|c|}
\hline & $\begin{array}{c}\text { (Full sample) } \\
\text { Party FE }\end{array}$ & $\begin{array}{c}\text { (Full sample) } \\
\text { Country FE }\end{array}$ & $\begin{array}{c}\text { (Full sample) } \\
\text { No FE }\end{array}$ & $\begin{array}{l}\text { (Non-GIIPS) } \\
\text { Country FE }\end{array}$ & $\begin{array}{c}\text { (GIIPS) } \\
\text { Country FE }\end{array}$ \\
\hline Misery & $\begin{array}{c}0.09 * * * \\
(0.02)\end{array}$ & $\begin{array}{c}0.09 * * * \\
(0.03)\end{array}$ & $\begin{array}{l}0.06^{*} \\
(0.03)\end{array}$ & $\begin{array}{l}0.07 * * \\
(0.03)\end{array}$ & $\begin{array}{c}-0.14 * * \\
(0.06)\end{array}$ \\
\hline Intervention & $\begin{array}{l}-0.06 \\
(0.34)\end{array}$ & $\begin{array}{c}0.37 \\
(0.34)\end{array}$ & $\begin{array}{c}0.39 \\
(0.31)\end{array}$ & & \\
\hline Intervention*Misery & $\begin{array}{c}-0.09 * * * \\
(0.03)\end{array}$ & $\begin{array}{c}-0.09 * * \\
(0.04)\end{array}$ & $\begin{array}{c}-0.09 * * \\
(0.04)\end{array}$ & & \\
\hline Incumbency & $\begin{array}{c}0.20 \\
(0.13)\end{array}$ & $\begin{array}{c}0.09 \\
(0.15)\end{array}$ & $\begin{array}{c}0.05 \\
(0.15)\end{array}$ & $\begin{array}{c}0.15 \\
(0.17)\end{array}$ & $\begin{array}{l}-0.05 \\
(0.20)\end{array}$ \\
\hline Party size & $\begin{array}{l}-0.01 \\
(0.01)\end{array}$ & $\begin{array}{l}-0.00 \\
(0.01)\end{array}$ & $\begin{array}{l}-0.00 \\
(0.01)\end{array}$ & $\begin{array}{l}-0.00 \\
(0.01)\end{array}$ & $\begin{array}{l}-0.00 \\
(0.01)\end{array}$ \\
\hline $\begin{array}{l}\text { Party type } \\
\text { (base: Christian dem) }\end{array}$ & & & & & \\
\hline Green & $\begin{array}{l}-0.96^{*} \\
(0.51)\end{array}$ & $\begin{array}{c}0.12 \\
(0.16)\end{array}$ & $\begin{array}{c}0.16 \\
(0.17)\end{array}$ & $\begin{array}{l}-0.01 \\
(0.14)\end{array}$ & $\begin{array}{c}0.37 \\
(0.41)\end{array}$ \\
\hline Communists & $\begin{array}{l}-0.15 \\
(0.45)\end{array}$ & $\begin{array}{l}0.31^{*} \\
(0.18)\end{array}$ & $\begin{array}{c}0.28 \\
(0.17)\end{array}$ & $\begin{array}{l}-0.19 \\
(0.20)\end{array}$ & $\begin{array}{l}0.68^{* *} \\
(0.34)\end{array}$ \\
\hline Social democrats & $\begin{array}{l}-0.19 \\
(0.36)\end{array}$ & $\begin{array}{c}0.09 \\
(0.15)\end{array}$ & $\begin{array}{c}0.08 \\
(0.15)\end{array}$ & $\begin{array}{l}-0.18 \\
(0.16)\end{array}$ & $\begin{array}{l}0.51^{*} \\
(0.28)\end{array}$ \\
\hline Liberals & $\begin{array}{l}-0.21 \\
(0.40)\end{array}$ & $\begin{array}{l}0.32 * * \\
(0.16)\end{array}$ & $\begin{array}{c}0.26 \\
(0.17)\end{array}$ & $\begin{array}{c}0.18 \\
(0.14)\end{array}$ & $\begin{array}{l}0.56^{*} \\
(0.34)\end{array}$ \\
\hline Conservatives & $\begin{array}{l}-0.20 \\
(0.28)\end{array}$ & $\begin{array}{c}0.17 \\
(0.18)\end{array}$ & $\begin{array}{c}0.16 \\
(0.18)\end{array}$ & $\begin{array}{c}0.21 \\
(0.23)\end{array}$ & $\begin{array}{c}0.43 \\
(0.26)\end{array}$ \\
\hline Nationalists & $\begin{array}{l}-0.69 \\
(0.42)\end{array}$ & $\begin{array}{l}-0.05 \\
(0.21)\end{array}$ & $\begin{array}{c}0.01 \\
(0.21)\end{array}$ & $\begin{array}{c}0.15 \\
(0.23)\end{array}$ & $\begin{array}{l}-0.12 \\
(0.32)\end{array}$ \\
\hline Agrarians & $\begin{array}{c}0.52 \\
(0.52)\end{array}$ & $\begin{array}{c}0.55 \\
(0.39)\end{array}$ & $\begin{array}{c}0.40 \\
(0.36)\end{array}$ & $\begin{array}{c}0.61 \\
(0.39)\end{array}$ & \\
\hline Ethnic/Regional & $\begin{array}{c}-1.08^{* *} \\
(0.43)\end{array}$ & $\begin{array}{l}-0.14 \\
(0.21)\end{array}$ & $\begin{array}{l}-0.07 \\
(0.21)\end{array}$ & $\begin{array}{l}-0.22 \\
(0.29)\end{array}$ & $\begin{array}{c}0.04 \\
(0.41)\end{array}$ \\
\hline Niche-issue & $\begin{array}{l}-0.52 \\
(0.46)\end{array}$ & $\begin{array}{l}-0.28 \\
(0.27)\end{array}$ & $\begin{array}{l}-0.29 \\
(0.28)\end{array}$ & $\begin{array}{c}-0.80 * * * \\
(0.31)\end{array}$ & $\begin{array}{c}0.32 \\
(0.49)\end{array}$ \\
\hline DV (lag $t-1)$ & $\begin{array}{c}-0.22 * * * \\
(0.07)\end{array}$ & $\begin{array}{c}0.25^{* * * *} \\
(0.07)\end{array}$ & $\begin{array}{c}0.36^{* * * *} \\
(0.07)\end{array}$ & $\begin{array}{l}-0.04 \\
(0.09)\end{array}$ & $\begin{array}{c}0.46^{* * * *} \\
(0.09)\end{array}$ \\
\hline Europhilia & $\begin{array}{c}-0.01 * * * \\
(0.00)\end{array}$ & $\begin{array}{c}-0.01^{* *} \\
(0.00)\end{array}$ & $\begin{array}{l}-0.00 \\
(0.00)\end{array}$ & $\begin{array}{c}-0.02 * * * \\
(0.00)\end{array}$ & $\begin{array}{l}0.01 * \\
(0.00)\end{array}$ \\
\hline ENEP & $\begin{array}{l}0.13 * \\
(0.08)\end{array}$ & $\begin{array}{l}-0.03 \\
(0.09)\end{array}$ & $\begin{array}{l}-0.00 \\
(0.03)\end{array}$ & $\begin{array}{c}0.04 \\
(0.15)\end{array}$ & $\begin{array}{l}-0.26 \\
(0.19)\end{array}$ \\
\hline Party FE & $\checkmark$ & $x$ & $x$ & $x$ & $x$ \\
\hline Country FE & $\checkmark$ & $\checkmark$ & $x$ & $\checkmark$ & $\checkmark$ \\
\hline Year effects & $\checkmark$ & $\checkmark$ & $\checkmark$ & $\checkmark$ & $\checkmark$ \\
\hline Constant & $\begin{array}{c}-4.55 * * * \\
(0.55)\end{array}$ & $\begin{array}{c}-2.68 * * * \\
(0.69)\end{array}$ & $\begin{array}{c}-2.34 * * * \\
(0.35)\end{array}$ & $\begin{array}{c}-4.09 * * * \\
(1.05)\end{array}$ & $\begin{array}{c}-2.18^{* *} \\
(0.92)\end{array}$ \\
\hline Observations & 339 & 339 & 339 & 194 & 145 \\
\hline R-squared & 0.72 & 0.42 & 0.38 & 0.53 & 0.52 \\
\hline
\end{tabular}


Table A 7: Panel-specific FE models

\begin{tabular}{|c|c|c|c|c|}
\hline & (Full sample) & (non-GIIPS) & (GIIPS) & (GIIPS) \\
\hline Misery & $\begin{array}{c}0.08 \\
(0.04)\end{array}$ & $\begin{array}{l}0.07^{*} \\
(0.03)\end{array}$ & $\begin{array}{c}-0.08 * * * \\
(0.01)\end{array}$ & \\
\hline Intervention & $\begin{array}{c}0.37 \\
(0.32)\end{array}$ & & & $\begin{array}{c}-0.52 * * * \\
(0.11)\end{array}$ \\
\hline Intervention*Misery & $\begin{array}{c}-0.10^{* *} \\
(0.04)\end{array}$ & & & \\
\hline Incumbency & $\begin{array}{c}0.01 \\
(0.10)\end{array}$ & $\begin{array}{c}0.18 \\
(0.15)\end{array}$ & $\begin{array}{l}-0.10 \\
(0.21)\end{array}$ & $\begin{array}{l}-0.10 \\
(0.21)\end{array}$ \\
\hline Party size & $\begin{array}{c}0.01 \\
(0.01)\end{array}$ & $\begin{array}{l}0.02^{*} \\
(0.01)\end{array}$ & $\begin{array}{l}-0.01 \\
(0.01)\end{array}$ & $\begin{array}{l}-0.01 \\
(0.01)\end{array}$ \\
\hline Europhilia & $\begin{array}{c}-0.01^{* *} \\
(0.00)\end{array}$ & $\begin{array}{l}-0.02 \\
(0.01)\end{array}$ & $\begin{array}{c}0.00 \\
(0.00)\end{array}$ & $\begin{array}{l}-0.00 \\
(0.00)\end{array}$ \\
\hline ENEP & $\begin{array}{c}0.04 \\
(0.10)\end{array}$ & $\begin{array}{l}-0.01 \\
(0.18)\end{array}$ & $\begin{array}{c}-0.25 * * * \\
(0.04)\end{array}$ & $\begin{array}{l}-0.09 \\
(0.09)\end{array}$ \\
\hline Year effects & $\checkmark$ & $\checkmark$ & $\checkmark$ & $\checkmark$ \\
\hline Constant & $\begin{array}{c}-3.76 * * * \\
(0.36)\end{array}$ & $\begin{array}{c}-3.29 * * \\
(0.99)\end{array}$ & $\begin{array}{c}-2.89 * * * \\
(0.21)\end{array}$ & $\begin{array}{c}-3.47 * * * \\
(0.43)\end{array}$ \\
\hline Observations & 424 & 226 & 198 & 198 \\
\hline R-squared & 0.27 & 0.28 & 0.35 & 0.35 \\
\hline Number of parties & 162 & 75 & 87 & 87 \\
\hline
\end{tabular}

Country-cluster robust standard errors in parentheses

$$
* * * \mathrm{p}<0.01, * * \mathrm{p}<0.05, * \mathrm{p}<0.1
$$




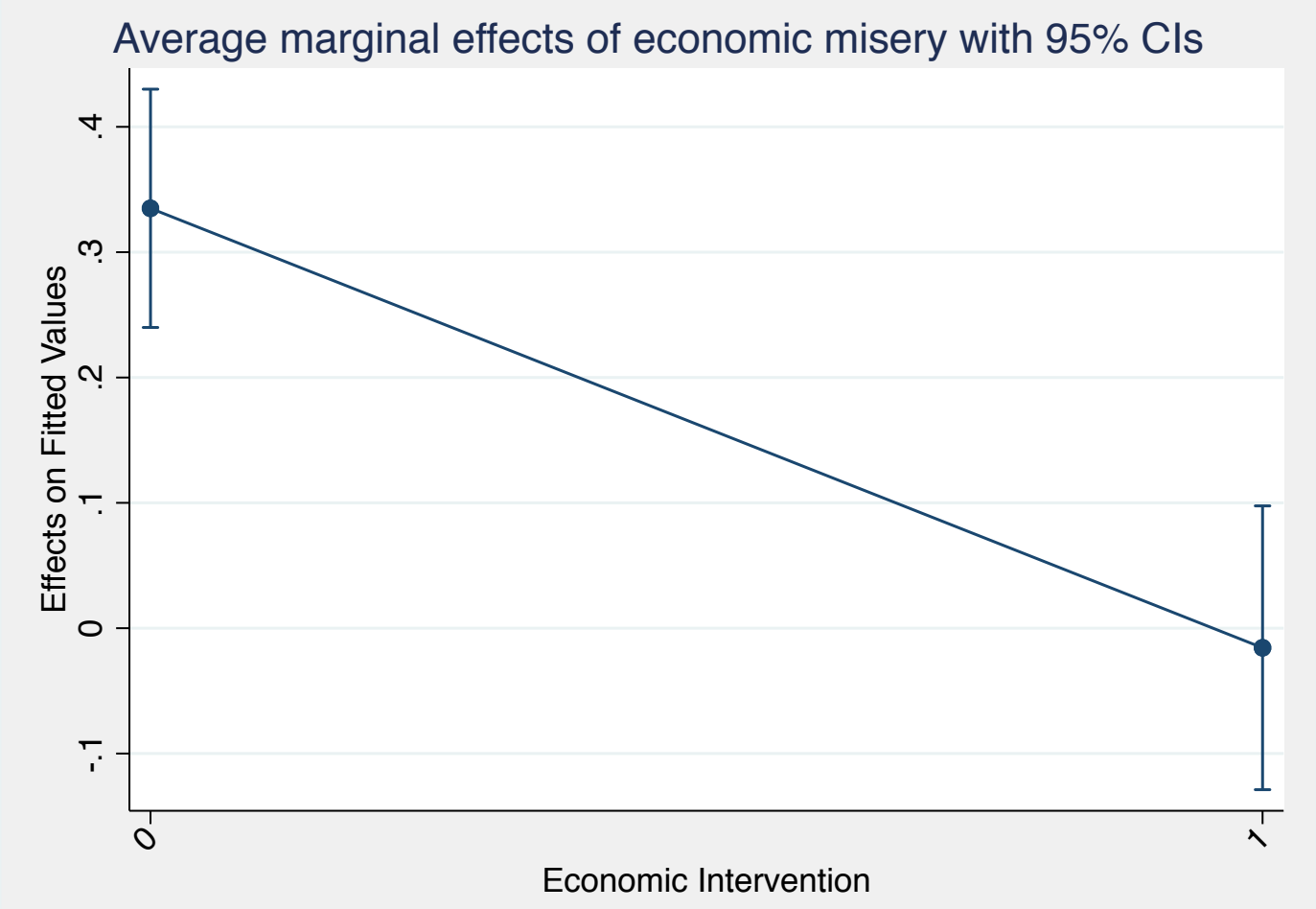

Figure A 1: AME on EU position

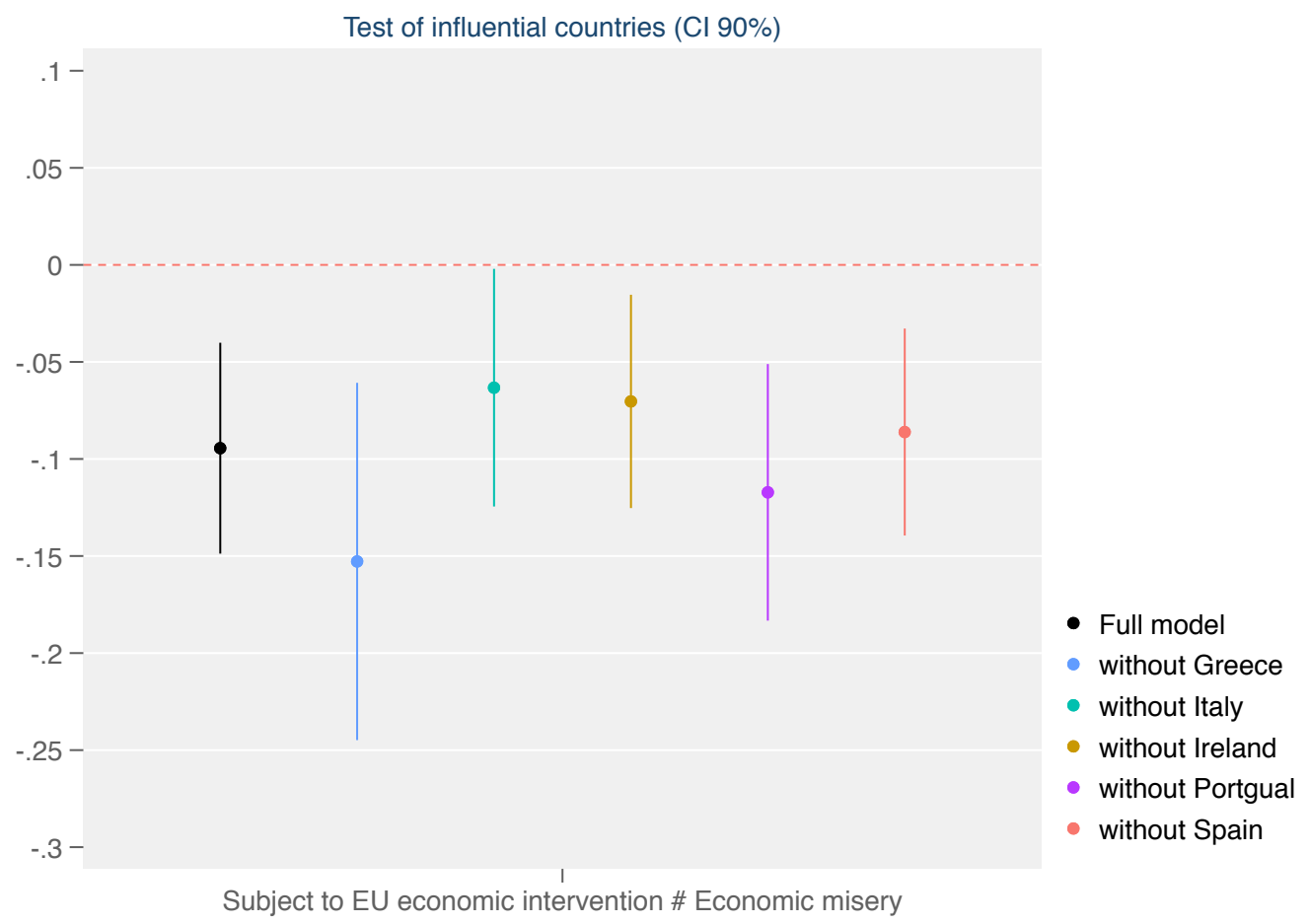

Figure A 2: Influential countries test (Saliency) 